Int. J. Dev. Biol. 57: 467-481 (2013)

doi: $10.1387 / \mathrm{ijdb} .130199 \mathrm{bl}$

\title{
The roles of bacterial and host plant factors in Agrobacterium-mediated genetic transformation
}

\author{
BENOÎT LACROIX* and VITALY CITOVSKY \\ Department of Biochemistry and Cell Biology, State University of New York, Stony Brook, NY, USA
}

\begin{abstract}
The genetic transformation of plants mediated by Agrobacterium tumefaciens represents an essential tool for both fundamental and applied research in plant biology. For a successful infection, culminating in the integration of its transferred DNA (T-DNA) into the host genome, Agrobacterium relies on multiple interactions with host-plant factors. Extensive studies have unraveled many of such interactions at all major steps of the infection process: activation of the bacterial virulence genes, cell-cell contact and macromolecular translocation from Agrobacterium to host cell cytoplasm, intracellular transit of T-DNA and associated proteins (T-complex) to the host cell nucleus, disassembly of the T-complex, T-DNA integration, and expression of the transferred genes. During all these processes, Agrobacterium has evolved to control and even utilize several pathways of host-plant defense response. Studies of these Agrobacterium-host interactions substantially enhance our understanding of many fundamental cellular biological processes and allow improvements in the use of Agrobacterium as a gene transfer tool for biotechnology.
\end{abstract}

KEY WORDS: Agrobacterium, genetic transformation, macromolecular transport, T-DNA expression

\section{Introduction}

Agrobacterium tumefaciens has served as an essential tool for research in plant biology and biotechnology in the last several decades (Newell, 2000). The exceptional ability of Agrobacteriumto transfer a part of its own DNA to the host plant genome represents a rare case of naturally occurring horizontal gene transfer, and is the basis of its use for transgenesis (Gelvin, 2003; Tzfira and Citovsky, 2006). This capability relies on a specialized plasmid, the tumorinducing ( $\mathrm{Ti}$ ) plasmid, that contains two essential regions required for DNA transfer to the host cell (Fig. 1). The presence of the Ti plasmid is responsible for the virulence of Agrobacterium, and a non-virulent strain may become virulent by acquiring this plasmid (Lacroix, 2013a). The first essential region is the transferred DNA (T-DNA) itself; it is delimited by two direct repeat sequences of about 25 base pairs, termed the left and right borders (LB and RB). These borders are necessary and sufficient to define a functional T-DNA element, while the transferred sequence between them may be modified at will. The T-DNA is not transported to the host plant cell as a double-stranded molecule; instead, VirD2 and VirD1, protein products of the Ti plasmid virulence region (see below), form a nuclease that nicks LB and RB, and a mobile single-stranded (ss) T-DNA form, termed the T-strand, is generated by strand replacement synthesis (Gelvin, 2003; Tzfira and Citovsky, 2006) (Fig. 1).
The second essential region, the virulence (vir) genes, composed of seven major loci (virA, virB, virC, virD, virE, virF, and virG), encodes most of the bacterial protein machinery required for virulence (Fig. 1) (Zupan and Zambryski, 1995). In the wild-type Agrobacterium, the T-DNA contains about fifteen genes that are expressed in the transformed plant cells and lead to the crown-gall disease (Escobar and Dandekar, 2003; Lacroix, 2013a). A subset of the T-DNA genes encodes proteins involved in plant growth regulator synthesis and sensitivity, which induce uncontrolled host cell division and result in the visible symptoms of Agrobacterium infection, i.e., tumors or crown galls. Other T-DNA gene products are involved in the production of opines, small secreted molecules that Agrobacterium cells use as source of carbon and nitrogen (Hooykaas, 1994).

\footnotetext{
Abbreviations used in this paper: ACC, 1-aminocyclopropane-1-carboxylate; AS, acetosyringone; DIMBOA, 2,4-dihydroxy-7-methoxy-2H-1,4-benzixazin-3(4H)one; DSB, double strand break; HR, homologous recombination; IAA, indole acetic acid; MDIBOA, 2-hydroxy-4,7-dimethoxybenzoxazin-3-one; NHEJ, non-homologous end joining; NLS, nuclear localization signal; rat, resistant to Agrobacterium tumefaciens; SA, salicylic acid; SCF, Skp1-Cullin-F-box protein; SAR, systemic acquired resistance; ss, single stranded; SSGR, single-strand gap repair; T-DNA, transferred DNA; Ti-plasmid, Tumor-inducing plasmid; T4SS, type four secretion system; UPS, ubiquitin/proteasome system; VBF, VIP1 binding F-box protein; VIP, VirE2 interacting protein; vir genes, virulence genes.
}

*Address correspondence to: Benoît Lacroix. Department of Biochemistry and Cell Biology, Stony Brook University, Stony Brook, NY, 11794-5215, USA. Tel.: +1-631-632-1015. Fax: +1-631-632-8575. E-mail: benoit.lacroix@stonybrook.edu

Final, author-corrected PDF published online: 16 October 2013

ISSN: Online 1696-3547, Print 0214-6282 
The natural host range of Agrobacterium in the plant Kingdom is very wide; species susceptible to Agrobacterium infection are found in most dicotyledonous and gymnosperm families, and in a few monocotyledonous families (De Cleene and De Ley, 1976). Under laboratory conditions, many other plant species that are not natural hosts can be made susceptible to Agrobacterium, for example by manipulating plant tissue culture conditions or artificially activating Agrobacterium virulence (Newell, 2000). However, generating stably transformed transgenic plants is still a challenge for many plant species, especially some agronomically important grains (Gelvin, 2010). In addition to plants, Agrobacterium mediated transformation of other eukaryotic species has been achieved under laboratory conditions (Lacroix et al., 2006): notably yeast (Bundock et al., 1995; Piers et al., 1996), many species of fungi (De Groot et al., 1998; Michielse et al., 2005), and even cultured human cells (Kunik et al., 2001).

In this article, we review the transfer of DNA between Agrobacterium and host cells (Fig. 1), focusing on the roles of plant factors in this process. In many ways, a better understanding of the diverse and critical functions of host factors in the transformation events may help to improve the efficiency of Agrobacterium-mediated genetic modification of species of interest. Moreover, Agrobacterium represents a unique experimental system to study the fundamental biological mechanisms and cellular systems, e.g., nuclear import machinery, chromatin targeting, proteasomal degradation, DNA repair, and regulation of transgene expression involved in genetic transformation of eukaryotic cells.

\section{Chemical communication between Agrobacterium and plant cells}

Because the activation of the bacterial virulence system represents a substantial investment of energy, a tight regulation of virulence induction in response to environmental stimuli is necessary. Indeed, the rhizosphere is a complex and dynamic environment, where plant-associated microorganisms constantly perceive different biotic signals and modify their behavior accordingly (Brencic and Winans, 2005). Specifically, Agrobacteriumdetects chemical signals emitted by host plants via its cell surface sensors and responds to them by optimizing the activity of its virulence system (Fig. 2).

The main and first discovered plant factor regulating Agrobacterium virulence is the phenolic compound acetosyringone (3,5-dimethoxyacetophenone, AS), present in plant cell exudates and capable of inducing the vir gene expression even in the absence of plant cells (Bolton et al., 1986; Stachel et al., 1985). AS is recognized by the bacteria via a two-component receptor system, composed of the VirA and VirG proteins (Klee et al., 1983; Stachel and Zambryski, 1986). The sensing of AS by the VirA/VirG receptor results in strong and rapid expression of all the virgenes. The virA and virG genes themselves are expressed at a low basal level in absence of AS, and are also highly inducible via a self-regulated system (Winans et al., 1988). Later, it was discovered that many other phenolic compounds resembling AS, including glycoside derivatives (Joubert et al., 2004), can also activate vir gene expression (Melchers et al., 1989a). Common structural features between these compounds, allowing them to interact with bacterial receptor, suggest that they are recognized by a unique protein at the surface of bacterial cell (Lee et al., 1992). Genetic studies have demonstrated that AS or related compounds bind directly to the
VirA protein (Lee et al., 1995); indeed, specific ranges of phenolic compounds recognized by different strains of Agrobacterium can be modified by exchanging their virA genes. Upon phenolic activator binding, VirA undergoes autophosphorylation and, in turn, phosphorylates VirG; the phosphorylated VirG targets a 12bp long specific sequence, termed the vir box, present in all vir operon promoters, which results in transcriptional activation of all

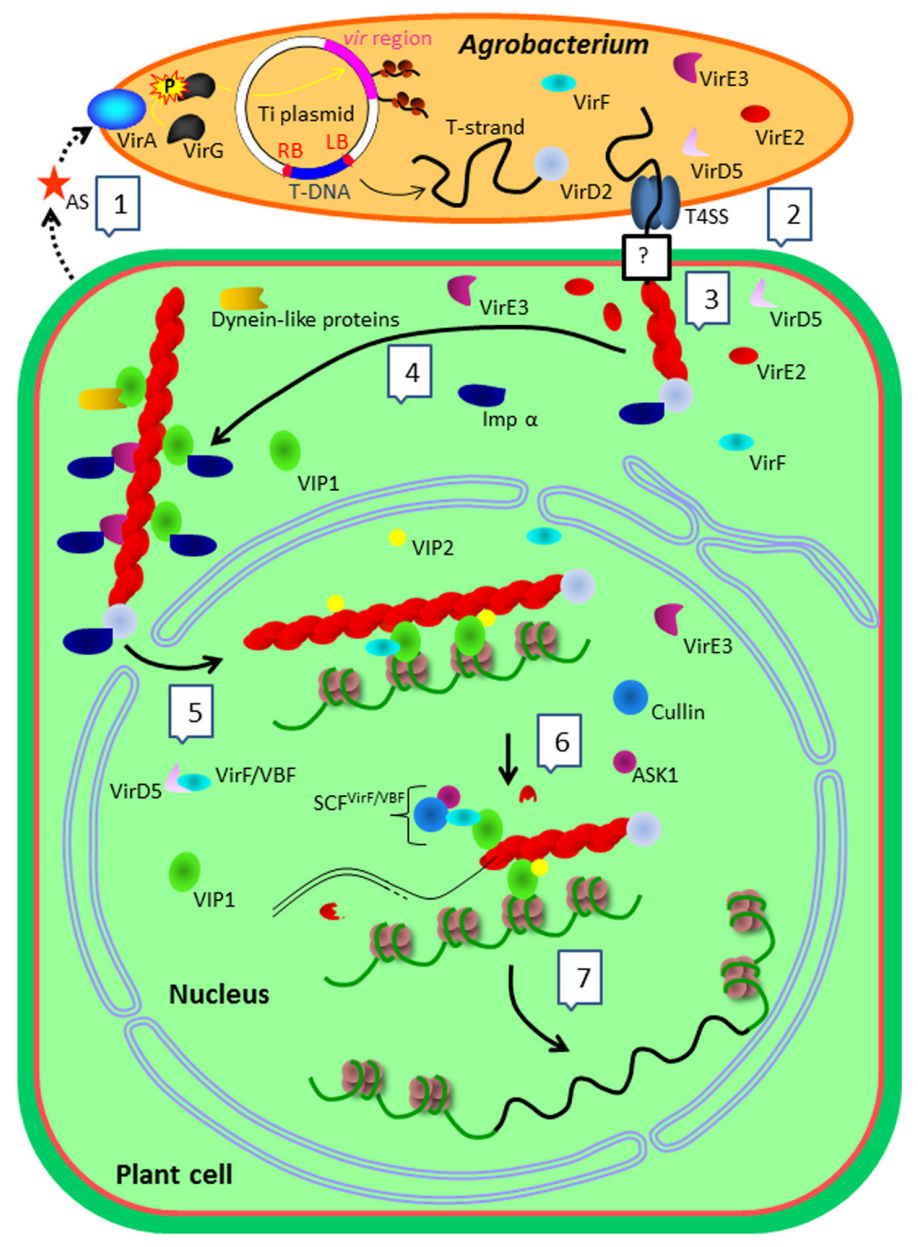

Fig. 1. Major steps in the process of transferred DNA (T-DNA) transfer and integration. Phenolic compounds, such as acetosyringone (AS), emitted by wounded plant tissue activate Agrobacterium vir gene expression via the VirA-VirG sensor (step 1), which results in generation of a mobile single-strandedT-DNA copy (T-strand). A complex composed of the T-strand and VirD2 covalently attached to its $5^{\prime}$ end is transported to the host cell cytoplasm via the bacterial type 4 secretion system (T4SS) (step 2), which also transports into the host cell four other bacterial virulence effectors (VirD5, VirE2, VirE3, and VirF). In the host cytoplasm, the mature T-complex is assembled by cooperative binding of VirE2 molecules along the T-strand molecule (step 3), and it is directed into the nucleus via interactions with the host cell proteins such as importin $\alpha$, VIP1 (or the bacterial VirE3), and dynein-like proteins, such as DLC3 (step 4). In the nucleus, the T-complex is targeted, presumably by interactions between VIP1 and the host chromatin, to the integration site (step 5), the associated proteins are removed by proteasomal degradation via the SCF VirFNBF pathway mediated by VirF or its host functional analog VBF (step 6), The T-strand is converted to a double-stranded form and integrated into the host genome by the host DNA repair machinery (step 7). 
vir genes (Brencic and Winans, 2005). The biosynthetic pathway for AS in plants is not completely characterized, but it has been shown that plants deficient in enzymes of the phenylpropanoid pathway are less susceptible to Agrobacterium, most likely because of reduced production of AS or related compounds (Maury et al., 2010). Interestingly, the expression levels of several genes encoding enzymes of this pathway increase upon Agrobacterium infection (Ditt et al., 2006). Because phenylpropanoids are involved, among other functions, in plant defense and survival (Fraser and Chapple, 2011); Agrobacterium may have evolved to subvert this host defense response to enhance its infection.

In addition to phenolic compounds, other signals emitted by plants affect vir gene expression. Reducing sugar monomers cannot activate the virulence system alone, but they are able to enhance AS action in two ways: by enhancing the sensitivity of the VirA/G system to phenolics and by elevating the saturating concentration of phenolics for virulence activation (Cangelosi et al., 1990; Shimoda et al., 1990). Additionally, the presence of monosaccharides as coinducers may result in increasing the range of phenolics recognized by the bacterial vir gene induction system (Peng et al., 1998). That the known coinducer monosaccharides, such as D-glucose and D-galactose (Ankenbauer and Nester, 1990; Shimoda et al., 1990), have common structural features, i.e., a pyranose ring and acidic groups, also suggests that they may be detected by a unique specific receptor. Indeed, a bacterial chromosome-encoded periplasmic protein ChvE mediates sensing of and virulence response to monosaccharides. ChvE is thought first to bind monosaccharides, and then to enhance the VirA activity as a vir gene inducer by interacting with the VirA periplasmic domain (Cangelosi et al., 1990; Lee et al., 1992; Shimoda et al., 1993).

Two conditions that are frequently observed in the rhizosphere, low $\mathrm{pH}$ and low phosphate concentration, are known to enhance activation of the virulence system. The effect of low pH, e.g., $\mathrm{pH} 5.7$, is mediated by VirA (Chang et al., 1996; Melchers et al., 1989b) and ChvE (Gao and Lynn, 2005). Moreover, the virG expression is induced by low $\mathrm{pH}$ and low concentration of phosphate, most likely via the activation of another two-component regulatory system composed of the ChvG and Chvl proteins (Charles and Nester, 1993; Yuan et al., 2008).

Chemicals emitted by some plant species can also act as inhibitors of the Agrobacterium virulence, which may help explain the important interspecific variability in resistance to Agrobacterium. Two chemical compounds found in corn seedling homogenates were shown to have such inhibitory effect: DIMBOA (2,4-dihydroxy7-methoxy-2H-1,4-benzixazin-3(4H)-one) is an inhibitor of both Agrobacterium growth and AS-dependent virulence activation (Sahi et al., 1990), and MDIBOA (2-hydroxy-4,7-dimethoxybenzoxazin-3-one) is a potent inhibitor of Agrobacterium virulence with a limited effect on bacterial growth (Zhang et al., 2000). DIMBOA and MDIBOA derive from the tryptophan biosynthetic pathway (Melanson et al., 1997), like the auxin indole acetic acid (IAA). In fact, IAA itself is able to inhibit vir gene induction, likely by competing with the inducing phenolic compounds, such as AS, for binding to VirA (Liu and Nester, 2006). Because IAA is produced at high concentrations during development of crown gall tumors resulting from Agrobacterium infection, it may inhibit secondary transformation by the initial infecting bacterial strain or by another competing strain.

Two signal molecules involved in plant response to several types of biotic or abiotic stresses have also been shown to act as negative regulators of Agrobacterium virulence. First, the phenolic compound salicylic acid (SA), the major signal molecule of systemic acquired resistance (SAR) (Vlot et al., 2009), inhibits expression of all vir genes, most likely by attenuating the VirA protein kinase activity (Yuan et al., 2007). Indeed, Arabidopsis or tobacco mutants deficient in SA accumulation are more sensitive to Agrobacterium infection, and mutants overproducing SA or plant treated with exogenous SA are relatively resistant (Anand et al., 2008; Yuan et al., 2007). Second, studies of plants affected in ethylene production suggested that this plant gaseous growth regulator can inhibit Agrobacterium virulence (Nonaka etal., 2008b). Consistently, inducing degradation of the direct precursor of ethylene 1-aminocyclopropane-1-carboxylate (ACC) in Agrobacterium cells by expression of ACC deaminase enhances transformation efficiency (Nonaka et al., 2008a). Yet, a direct effect of ethylene on vir gene expression could not be demonstrated.

\section{Cell-to-cell contact and attachment}

Intuitively, it is logical to assume that a close contact between Agrobacterium cells and their host cells is required for T-DNA transfer. Indeed, Agrobacterium mutants affected in their ability to attach to plant cells usually show reduced virulence (Matthysse, 1987). However, whereas several candidates have been proposed

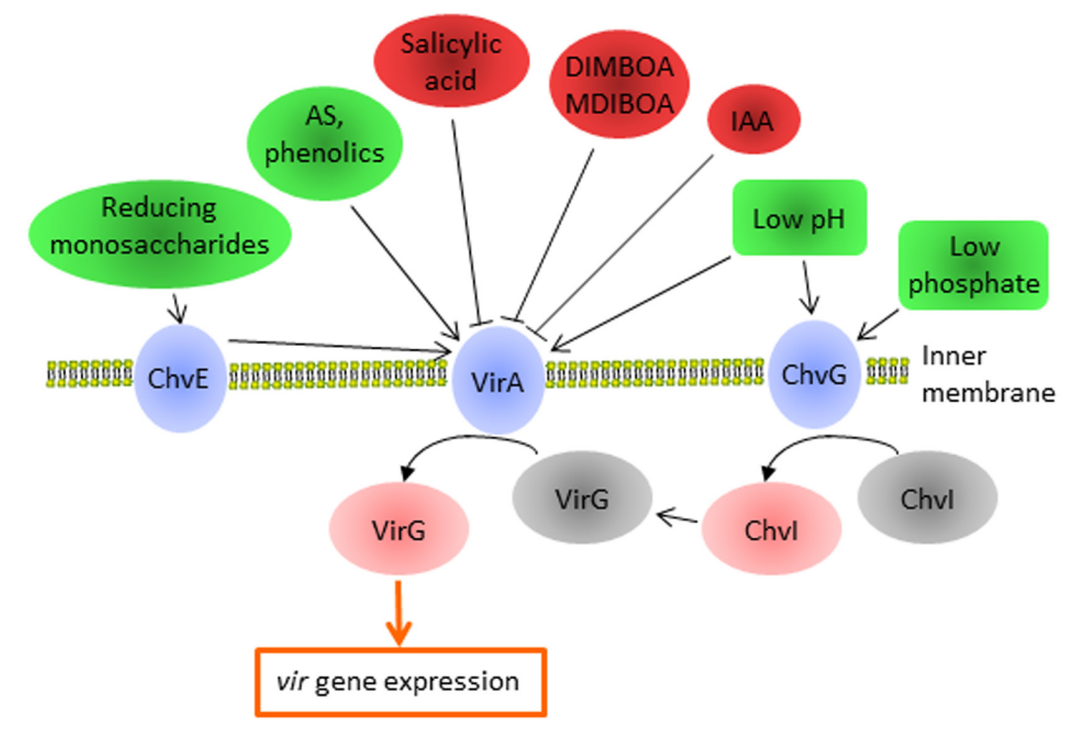

Fig. 2. Plant factors affecting vir gene expression. The Agrobacterium VirANirG twocomponent regulatory system integrates numerous plant and environmental signals to regulate transcription of the vir genes. Small molecules directly bind VirA to promote [acetosyringone (AS) and related phenolic compounds], or inhibit (salicylic acid, DIMBOA, MDIBOA, IAA) VirG activation and enhancement of its expression. Reducing monosaccharides bind to ChvE, which in turn interacts with VirA to enhance AS-induced vir activation. Low $\mathrm{pH}$ and low phosphate concentration have a positive effect on vir activation by affecting either directly VirA or the ChvG-Chvl two-component system that in turn activates the virG expression. 
for the roles of the putative plant or bacterial cell surface receptors, to date this function has not been confirmed for any of them. Like in many other cases of plant-associated bacteria, cell-to-cell contact is believed to occur in two sequential stages (Rodriguez-Navarro et al., 2007; Tomlinson and Fuqua, 2009). First, a reversible attachment is mediated by bacterial and plant extracellular factors, adhesins; however, none of such molecules have yet been identified for the Agrobacterium-plant cell interaction. Second, the initial attachment is consolidated via the synthesis of bacterial exocellular glucans leading to biofilm formation (Matthysse, 1983; Tomlinson and Fuqua, 2009).

On the bacterial side, numerous genes have been proposed to play a role in the initial attachment; however, for most of them, a function could not be defined, and many of them were found to be not essential for virulence. Extracellular components of the type IV secretion system (T4SS), i.e. VirB1*, VirB2, and VirB5, are good candidates for interacting with a potential plant receptor. Specifically, VirB2 and VirB5 have been suggested to function as adhesins, based on the fact that their orthologs play this role in other pathogenic bacteria, such as Brucella sp. (Backert et al., 2008). However, it is still unknown whether these VirB proteins are involved in the early steps of cell-cell recognition, and their only proven classical function remains the transport of the bacterial T-DNA and effector proteins into the host cell cytoplasm. Furthermore, the available data suggest that the entire vir region is not essential for bacterial attachment. Another subset of the Agrobacterium genes, the att region located in the pAt linear chromosome, have initially been suspected to mediate attachment (Matthysse and Mcmahan, 1998); however later studies demonstrated that the att genes are not required for Agrobacterium virulence, but are mainly involved in quorum sensing (Nair et al., 2003). Finally, only three bacterial factors, i.e., the chromosome-located $\operatorname{chv} A, \operatorname{chv} B$, and exoCgenes involved in synthesis of exocellular oligosaccharides, such as the cyclic 1,2- $\beta$-D-glucan, have been unequivocally shown to play an essential role in both attachment and virulence (Cangelosi et al., 1989; De lannino and Ugalde, 1989). But what are the host factors that might recognize and bind these exopolysaccharides of Agrobacterium?

Lectins, a family of plant proteins that bind reversibly mono- or oligosaccharides, are known to interact with exopolysaccharides of several species of Rhizobiaceae (Hirsch, 1999). Similarly, host lectins could be involved in recognition of the Agrobacterium exocellular cyclic glucan produced via the chvA, chvB, and exoC system; as yet, however, no such lectins have been identified.

Another potential candidate for initial attachment of Agrobacterium to the host cell is rhicadhesin. Rhicadhesin was first identified as an extracellular protein in Rhizobium, and it inhibits the attachment of both Agrobacterium and Rhizobium cells to the plant cell surface, potentially by saturating a host receptor (Smit et al., 1989). However, no genes encoding rhicadhesin-like proteins are found in the Agrobacterium genome. In plants, putative receptors for rhicadhesin-like molecules have been identified, such as a carrot cell surface vitronectin-like protein (Wagner and Matthysse, 1992) or a pea cell wall germin-like glycoprotein (Swart et al., 1994). However, their role in bacterial attachment and actual binding to rhicadhesin have never been substantiated, and a more recent study has demonstrated that a vitronectin-like protein present in the Arabidopsis cell wall is involved neither in attachment nor in virulence of Agrobacterium (Clauce-Coupel et al., 2008).
Aforward genetic screen for Arabidopsis resistant to Agrobacterium (rat) mutants lead to identification of several plant lines mutated in genes encoding extracellular proteins, potentially involved in bacterial attachment. For example, the rat4 mutant is deficient in a homolog of cellulose synthase, CSLA9, raising a possibility that modifications of the plant cell surface by CSLA9 could affect bacterial attachment (Zhu et al., 2003a). That Agrobacterium is also able to infect fungi and animal cells suggests that a plant-specific receptor is not absolutely required for virulence. Nevertheless, in nature, Agrobacterium strains able to bind to a plant receptor to enhance the cell-to-cell contact would certainly gain advantage in competing with bacterial strains that cannot recognize such receptor(s).

In the second stage, the attachment of Agrobacterium to hostcell is consolidated, mostly by the synthesis of bacterial cellulose fibrils and cyclic glucans, which results in the formation of a biofilm in which bacteria are embedded at the plant cell surface. Biofilm formation appears essential for the virulence of most plant-associated bacteria (Danhorn and Fuqua, 2007), including Agrobacterium (Matthysse et al., 2005; Tomlinson et al., 2010). However, whereas Agrobacterium mutants disrupted in the celABCDE operon are unable to synthesize cellulose and are impaired in their attachment to plant cells, their tumorigenicity is only slightly diminished (Matthysse, 1983). Thus, unlike cyclic glucans (Cangelosi et al., 1989; De Iannino and Ugalde, 1989), cellulose fibrils are not absolutely required for Agrobacterium virulence. As mentioned above, there are no known plant factors that interact with bacterial exocellular glucans during the initial attachment stage; however, these glucans might play a role in determination of structural and chemical properties of the host cell surface that, in turn, may affect the formation of biofilms during the attachment consolidation stage.

\section{Transferred-DNA and protein entry into host plant cell}

Agrobacterium T-DNA and protein translocation into the host cell is mediated by the bacterial T4SS, composed of the eleven proteins encoded by the virB operon and the virD4 gene. Agrobacterium T4SS is particularly well studied, and T4SS structure and the functions of its protein components are well understood (Christie, 2004), including the sequence of contacts of the T-DNA transport substrate with different subunits of T4SS (Cascales and Christie, 2004). However, the mechanism by which T4SS traverses the plant cell wall and plasma membrane for delivery of the transport substrates, i.e., the T-DNA and effector proteins, into the host cell cytoplasm remains unknown.

Because the T-pilus represents the extracellular appendage of the T4SS, the role of its components, mainly of VirB2 and VirB5, and their potential interactions with plant cell surface factors could provide clues for understanding how T4SS negotiates these cellular barriers. In a yeast-two-hybrid screen, four plant proteins interacting with the processed carboxyl terminal VirB2, i.e., VirB2 lacking the amino terminal 42 amino acid-long signal peptide cleaved before the T-pilus biogenesis, were identified (Hwang and Gelvin, 2004). Three of them are related proteins of unknown function, designated BTI1, 2, and 3, and the fourth is a membrane-associated GTPase, AtRAB8. Plant susceptibility to Agrobacterium correlates with the expression levels of these proteins (Hwang and Gelvin, 2004). Thus, these proteins are good candidates for the role of plant receptors mediating interaction with the T-pilus, albeit it has not been determined whether they are involved in the early stages 
of the Agrobacterium-plant cell interaction or in the process of macromolecular translocation itself. Similarly, although the exact function of VirB5 is unknown, its extracellular localization, most likely at the tip of the T-pilus, indicates possible interactions with a host cell surface factor (Aly and Baron, 2007). Consistent with this idea, exogenous extracellular VirB5 protein enhances infectivity of the wild-type Agrobacterium, although it does not rescue infectivity of an Agrobacterium mutant disrupted in the virB5 gene (Lacroix and Citovsky, 2011). These observations suggest a dual role for VirB5: intrabacterial function for biosynthesis and/or stability of the T-pilus, and an extracellular function. Interestingly, CagL, an ortholog of VirB5 in the animal pathogen Helicobacter pylori, interacts with the host integrin; whether this interaction plays a role in macromolecular translocation, or it is simply involved in triggering intracellular signaling in the host cell, remains unknown (Tegtmeyer et al., 2011).

Similarly to protein translocation by type III secretion systems (Thanassi et al., 2012), macromolecules translocated by T4SS could be injected directly from the bacterial to the host cytoplasm through the T-pilus acting as a hollow needle (Kado, 2000). The T-pilus has a lumen diameter of $2 \mathrm{~nm}$, compatible with the passage of folded protein and ssDNA molecules (Kado, 2000). Alternatively, the T-pilus may act by mechanically perforating the host cell wall and plasma membrane, thus allowing the entry of the transported molecules through a T4SS transport conduit (Llosa et al., 2002). That these two possible modes of macromolecule translocation do not postulate a plant-specific receptor is consistent with the Agrobacterium's ability to transfer macromolecules to a wide variety of eukaryotic cells, including non-plant hosts (Lacroix et al., 2006). Another series of studies suggested that T-DNA transfer can occur even in absence of detectable levels of T-pilus biogenesis. Indeed, substrate transfer through the Agrobacterium T4SS is not abolished by the blocking VirB2 polymerization and, thus, inhibition of the T-pilus formation (Sagulenko et al., 2001).

A radically different mechanism invoked for the entry of T-DNA into the host cell relies upon the formation of protein channels in lipidic membrane, composed of the Agrobacterium VirE2 protein (Dumas et al., 2001). Such channels may allow the passage of macromolecules through host membrane. In addition, the very efficient and cooperative binding of VirE2 (Citovsky et al., 1989) to the T-strand in the host cell cytoplasm may actively pull the T-DNA molecule out of the T4SS and/or VirE2 channels, without requiring external energy sources (Grange et al., 2008). The biological relevance of these VirE2 activities for the actual transformation process remains to be demonstrated in vivo, and potential VirE2interacting plant factors that may be involved in this process await to be discovered.

\section{Nuclear import}

Because the final destination of the T-DNA is the host cell nucleus, where it is to be integrated in the host genome, T-DNA targeting to the nucleus and passage through the nuclear pore represent an important step of the genetic transformation process. The T-DNA nuclear import is mediated by bacterial effector proteins, VirD2 and VirE2, associated with the T-DNA and several host proteins that interact with these effectors. This interaction network is summarized in Fig. 3.

The bacterial endonuclease component VirD2, which is cova- lently associated with the 5' end of the exported T-strand molecule (Ward and Barnes, 1988; Young and Nester, 1988) (see Fig. 1), interacts directly with the plant importin $\alpha$, a component of the cellular nuclear import machinery, that mediates the nuclear import of VirD2 (Ballas and Citovsky, 1997), and, by implication its associated T-strand. Two nuclear localization signals (NLSs) are found within VirD2, a monopartite amino terminal NLS and a bipartite carboxyl terminal NLS (Herrera-Estrella et al., 1990; Howard et al., 1992; Tinland et al., 1992), but only the latter is necessary for the VirD2 nuclear import (Howard et al., 1992; Ziemienowicz et al., 2001). In addition, two other plant proteins interacting with VirD2 might modulate its nuclear localization: an Arabidopsis cyclophilin that may further assist VirD2 nuclear import (Deng et al., 1998); and a tomato type $2 \mathrm{C}$ serine/threonine protein phosphatase is thought to dephosphorylate VirD2 and thereby inhibit its nuclear import, although the role of VirD2 phosphorylation in the nuclear import has not been demonstrated directly (Tao et al., 2004).

The VirE2 nuclear import is more complex. Unlike VirD2, VirE2 does not interact efficiently with importin $\alpha$ (Citovsky et al., 2004), although recent data have detected such interaction with one specific member of this protein family (Bhattacharjee et al., 2008) (see below). Instead, it relies on the presence of the VirE2 interacting

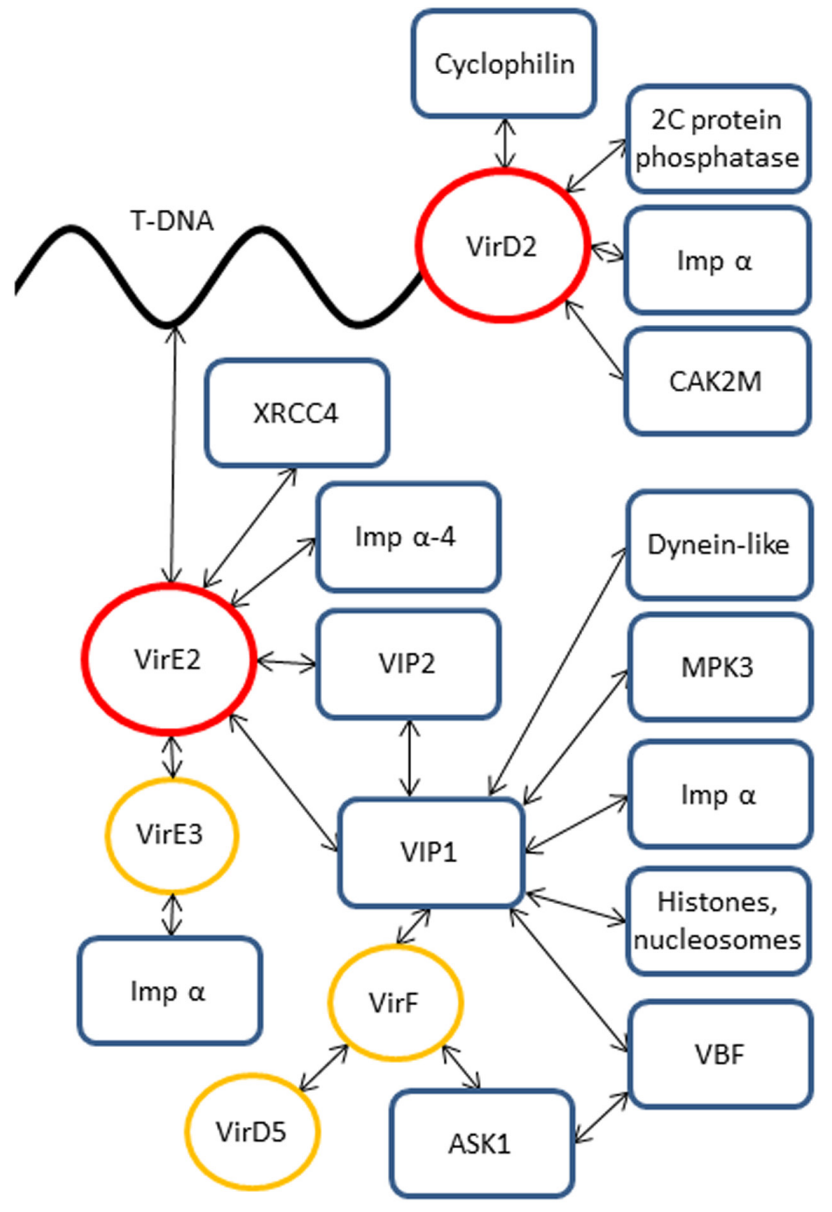

Fig. 3. Network of interactions between translocated Agrobacterium effectors and host cell proteins. Blue rectangles, host factors; yellow circles, bacterial effector proteins; red circles, bacterial effector proteins directly associated with the T-strand. For other details, see text. 
protein 1 (VIP1), a plant basic leucine zipper (bZIP) motif protein (Tzfira et al., 2001). VIP1 has been shown to act as a molecular adapter between VirE2 and the host nuclear import machinery by binding directly to both VirE2 and importin $\alpha$ (Citovsky et al., 2004; Tzfira et al., 2001; 2002). Thus, both VirD2 and VirE2 are imported into the host cell nucleus via the importin $\alpha$-dependent pathway, VirD2 - directly, and VirE2 - largely by piggybacking on VIP1. The nuclear localization of VIP1 itself is regulated by serine phosphorylation at position 79 by the mitogen-activated protein (MAP) kinase 3 (MPK3) (Djamei et al., 2007). MAP kinases are important signal transduction factors involved in plant responses to many biotic and abiotic stimuli (Colcombet and Hirt, 2008), and MPK3 is activated during plant defense reactions by several factors, including Agrobacterium infection. Moreover, an Arabidopsis mutant in the MPK3 gene is resistant to Agrobacterium (Djamei et al., 2007). Therefore, the induction of MPK3 and subsequent phosphorylation of VIP1, which are normally part of the plant defense reaction, are subverted by Agrobacterium to enhance its infectivity (Djamei et al., 2007).

In general, Agrobacterium might "choose" different cellular pathways to achieve successful infection, which rely on bacterial or plant factors according to the host species and/or physiological conditions. For example, it has been shown that VirE2 can also interact directly with some members of the plant importin $\alpha$ family, such as importin $\alpha-4$ (Bhattacharjee et al., 2008), which potentially assist its nuclear import in the absence, or in addition to, VIP1. Yet it remains unclear whether this interaction, indeed, is functionally important for the VirE2 nuclear import. Unlike VIP1, which can bind VirE2 when the latter is associated with SsDNA (Lacroix et al., 2008), it remains unknown whether importin $\alpha-4$ can also bind VirE2 in such nucleoprotein complex.

Interestingly, VirE3, another Agrobacterium virulence protein translocated into the plant cell, partially mimics the VIP1 function: it can interact with both VirE2 and importin $\alpha$ and facilitate the nuclear import of VirE2 (Lacroix et al., 2005). VirE3 is not absolutely essential for plant genetic transformation by Agrobacterium, but might compensate for the lack of VIP1-like protein in some plant species, consistent with its proposed role as a host range factor (Hirooka and Kado, 1986). VirE3 nuclear import relies on the canonical bipartite NLS (Lacroix et al., 2005); curiously, like VIP1, VirE3 has been suggested to act as transcription factor, although its potential target genes are unknown (Garcia-Rodriguez et al., 2006). Two other Agrobacterium virulence proteins known to be exported into the host-plant cell, VirD5 and VirF (see below), are also targeted to the nucleus (Magori and Citovsky, 2011; Tzfira et al., 2004b), likely by direct interaction with the host cell nuclear import machinery.

Soon after their entry in the host cell cytoplasm, the VirD2-Tstrand complex and VirE2 molecules - thought to be translocated into the host cell independently of each other (Citovsky et al., 1992; Gelvin, 1998; Otten et al., 1984; Vergunst et al., 2000)-most likely associate to form the mature T-complex. Because the major structural components of the T-complex are the T-strand and VirE2, and because T-DNA is not sequence-specific (Zambryski, 1992), VirE2-ssDNA complexes can be considered to represent a minimal synthetic T-complex (Abu-Arish et al., 2004; Citovsky et al., 1997; Dym et al., 2008; Lacroix et al., 2008; Zupan et al., 1996). Structural analyses of these synthetic T-complexes (Abu-Arish et al., 2004; Citovsky et al., 1997; Grange et al., 2008) indicated a coiled filament with a 13-15 nm diameter (Abu-Arish et al., 2004), which is larger than the 9-nm diffusion limit of the nuclear pore (Forbes, 1992). Based on these parameters, a typical mature T-complex from a nopaline-specific Agrobacterium strain (Citovsky et al., 1992) would be composed of a 22-kb T-strand, 1,176 molecules of VirE2, and one molecule of VirD2, with a total molecular mass of about 90 megadaltons; the movement of such a large complex trough the cytoplasm by diffusion would be very limited (Tzfira, 2005), and its passive entry into the nucleus impossible (Forbes, 1992). Therefore, nuclear import of the T-complex as well as its transcytoplasmic transport toward the nucleus most likely occur by active mechanisms. Due to the sequence non-specific nature of the T-strand, the T-complex nuclear import must rely on the nuclear targeting abilities of its protein components, VirE2 and VirD2, and thus occur via the importin $\alpha$-dependent pathway. Indeed, VirD2, as well as VirE2, can mediate nuclear import of short segments of ssDNA, independently of each other, in animal (Ziemienowicz et al., 1999) and in plant cells (Gelvin, 1998; Zupan et al., 1996). Although these data suggest a redundancy between VirD2 and VirE2 roles in nuclear import of the T-complex, an efficient transport of the T-complex through the nuclear pore, which is thought to occur in a polar fashion (Tzfira et al., 2000; Zambryski, 1992), is likely to require both factors (Ziemienowicz et al., 2001). Consistent with the polar structure of the T-complex, VirD2, attached to the 5'-end of the T-strand, may direct the T-complex toward the nuclear pore, while VirE2 and its associated VIP1 or VirE3, that package the entire length of the T-strand, assist the translocation process, bringing it to completion. Lending support to this model, Agrobacteriummediated genetic transformation with very long (about $150 \mathrm{~kb}$ ) segments of DNA is enhanced by expressing additional copies of the virE2 gene in the bacterium (Hamilton et al., 1996).

Many DNA viruses depend on molecular motors, such as dynein, and the microtubule network for their transcytoplasmic transport (Dodding and Way, 2011). Two lines of evidence suggest a similar role for molecular motors in the T-complex movement through the host cell cytoplasm. First, VIP1, a T-complex associated host protein, has been shown to interact with the dynein-like DLC3 protein of Arabidopsis(Tzfira, 2006). Second, the observations that synthetic T-complexes are actively transported along the microtubule network in a cell-free system suggest the involvement of cytoskeletal elements in the infection process (Salman et al., 2005).

\section{Chromatin targeting of T-complex}

In the nucleus, the T-DNA needs to be targeted to the chromatin before its potential integration into the host genome. To understand this process, it necessary first is to determine whether Agrobacterium T-DNA is integrated (and, by implication, chromatin-targeted) randomly or preferentially in specific genomic domains. A series of studies, analyzing genome-wide distribution of T-DNA integration sites in Arabidopsis, indicated a bias toward transcriptionally active chromatin and the regulatory regions of genes (Alonso et al., 2003; Chen et al., 2003). However, in these studies, the recovery of transgenic plants used for integration analyses relied on the expression of a reporter or a selectable marker transgene, which introduced obvious bias in the nature of the recovered insertion events: high incidence of recovery of insertions into euchromatin and underrepresentation of insertions into heterochromatic regions. However, when the integration events were recovered 
without selection pressure, i.e., independent on transgene expression, they proved to be truly random, without bias toward active chromatin (Dominguez et al., 2002; Kim et al., 2007). That T-DNA has access to all areas of the host chromatin raises the question of a mechanism modifying the structure of the heterochromatin to render it accessible to T-DNA during Agrobacterium infection. Interestingly, an earlier study suggested that T-DNA integration may require that the host cell go through the S-phase of the cell cycle (Villemont, 1997), during which chromatin decondenses. Thus, if T-DNA integration indeed, occurs when the target chromatin is already naturally decondensed, there is no need for involvement of a specific factor that induces decondensation. Alternatively, plant responses to Agrobacterium infection as well as to other stress factors may converge on the dedifferentiation process whereby cells first acquire stem cell-like state with decondensed chromatin prior to acquisition of a new cell fate (Grafi et al., 2011).

Some of the plant factors interacting with protein components of the T-complex may mediate its targeting to the host chromatin. For example, the VirD2 interactor CAK2M, a conserved plant ortholog of cyclin-dependent kinase-activating kinase, also binds to a subunit of RNA polymerase II, which recruits TATA box-binding proteins (TBPs) (Bako et al., 2003). The association of VirD2 with CAK2M, and with TBPs, could play a role in chromatin targeting of the T-complex, and it might also explain the bias toward T-DNA integration into gene regulatory regions found in some studies (e.g., Alonso et al., 2003). VIP1 is another potential host factor involved in chromatin targeting of the T-complex; as a plant transcription factor (Djamei et al., 2007), it is expected to associate with the cell chromatin. Indeed, VIP1 can bind the four types of Xenopus core histones in vitro (Loyter et al., 2005), and at least one plant histone, $\mathrm{H} 2 \mathrm{~A}$, in vivo (Li et al., 2005a). Moreover, VIP1 exhibits strong interaction with purified plant nucleosomes in vitro (Lacroix et al., 2008); because this interaction is competitively inhibited by $\mathrm{H} 2 \mathrm{~A}$, this histone likely represents a VIP1 binding site in a nucleosome context. Furthermore, VIP1 is also able to mediate the association of VirE2 as well as the synthetic minimal T-complex to plant nucleosomes in vitro by formation of the quaternary nucleosomeVIP1-VirE2-ssDNA complexes (Lacroix et al., 2008). This model of VIP1-mediated T-complex chromatin targeting is also consistent with the requirement for $\mathrm{H} 2 \mathrm{~A}$ and other core histones for T-DNA integration (Mysore et al., 2000; Yi et al., 2002).

Like VIP1, VIP2 is a plant transcription factor that interacts with VirE2 (Anand et al., 2007). Because VIP2 is required for stable plant genetic transformation, but not for transient T-DNA expression, it is thought to play a role in T-DNA integration (Anand et al., 2007). The mechanism of the VIP2 effect on T-DNA integration is not yet understood. As a transcription factor, VIP2 modifies the expression levels of many genes, including core histones (Anand et al., 2007), suggesting that it may affect T-DNA integration indirectly via altering histone expression. Or, VIP2, also like VIP1, could be involved in chromatin targeting, mediating between VirE2 of the T-complex and chromatin.

Potential role of other host factors in the T-complex chromatin targeting is also likely. For example, because double-stranded DNA break (DSB) repair is the main mechanism involved in T-DNA integration (Chilton and Que, 2003; Salomon and Puchta, 1998; Tzfira et al., 2003) (see below), interaction between the T-complex and a component of the host DNA repair machinery and/or DSBassociated proteins - such as BRCA which specifically localizes to
DSBs, or a phosphorylated form of histone $\mathrm{H} 2 \mathrm{AX}(\gamma \mathrm{H} 2 \mathrm{AX})$ which delineates chromatin domain around DSB (Friesner et al., 2005) might help direct the T-complex to DSBs in the host chromatin.

\section{Disassembly of T-complex}

Whereas VirE2 and VIP1 are critical for nuclear import and chromatin targeting of the T-complex, they become a liability for integration as they physically mask the DNA molecule. Thus, once the T-complex reaches the host chromatin, its proteins must be removed for the reactions of the second strand synthesis (see below) and integration. This disassembly is mediated by the host ubiquitin/proteasome system (UPS) (Tzfira et al., 2004b; Zaltsman et al., 2010a; Zaltsman et al., 2010b). The first indication for the involvement of UPS in Agrobacterium infection came from identification of VirF, a bacterial host range factor exported into the host cell (Regensburg-Tuink and Hooykaas, 1993), as an F-box protein (Schrammeijer et al., 2001) and subsequent identification of its cellular substrate, VIP1 (Tzfira et al., 2004b). Characteristic of the F-box proteins (Ho et al., 2006; Lechner et al., 2006), VirF interacts with several Arabidopsis ASK proteins (Schrammeijer et al., 2001), homologs of the yeast Skp1 component of SCF. F-box proteins and Skp1 are components of the SCF (Skp1-Cullin-F-box protein) complexes, which represent E3 ubiquitin ligases mediating targeted protein destabilization by the $26 \mathrm{~S}$ proteasome (Cardozo and Pagano, 2004).

Both VirF and ASK1 are located in the plant cell nucleus (Schrammeijer et al., 2001; Tzfira et al., 2004b), where the T-complex uncoating is expected to occur. VirF binds to VIP1 and promotes its degradation in plant and yeast cells (Tzfira et al., 2004b). Moreover, VirF is able to promote also the degradation of VirE2 in the presence of VIP1, even though VirF does not recognize VirE2 directly, suggesting that VirF can induce the destabilization of the entire VIP1-VirE2 complex. VIP1 and VirE2 destabilization occurs via the SCF ${ }^{\text {VirF }}$ pathway; indeed, in yeast cells, this destabilization does not occur in a conditional skp1-4 mutant and requires the presence of active Skp1 (Tzfira et al., 2004b). An additional layer of regulation of the SCF ${ }^{\text {VirF }}$ activity may be introduced by the bacterial exported effector VirD5, which binds VirF and prevents its rapid turnover by the defensive action of the host UPS (Magori and Citovsky, 2011).

VirF, considered as a host range factor, enhances Agrobacterium infectivity in tomato and Nicotiana glauca, but is not required for infection of tobacco or Arabidopsis plants (Melchers et al., 1990; Regensburg-Tuink and Hooykaas, 1993). Potentially, the plant species that do not require VirF, possess an endogenous F-box protein able to fulfill the VirF function during Agrobacterium infection. Indeed, a VIP1-binding F-box protein (VBF), an Arabidopsis F-box protein induced by Agrobacterium infection (Ditt et al., 2006), was identified and found to bind VIP1 and promote proteasomal destabilization via the SCF ${ }^{\mathrm{VBF}}$ pathway of VIP1 and VIP1-VirE2 complexes in yeast and plant cells (Zaltsman et al., 2010b). In addition, an Arabidopsis mutant impaired in VBF expression displayed increased resistance to Agrobacterium-induced tumor formation, whereas VBF expressed in Agrobacterium and exported to the host cell enhanced infectivity of a VirF-lacking bacterial strain in tomato plants (Zaltsman et al., 2010b). The ability of VBF to promote unmasking of ssDNA packaged by VirE2 was demonstrated directly in a cell-free system, where uncoating of synthetic minimal T-complexes and exposure of ssDNA by plant protein extracts 
was accelerated in presence of exogenous VIP1 and inhibited by proteasome-specific inhibitors, and was dependent of the presence of a functional VBF (Zaltsman et al., 2013).

\section{Integration of Transferred-DNA}

Recent discoveries have substantially changed our vision of the mechanism of Agrobacterium T-DNA integration into the host genome (Tzfira et al., 2004a). Generally, studies of T-DNA integration in plant, in yeast, and in vitro experimental systems have demonstrated that integration is largely dependent on the host DNA repair machinery and relegated comparatively minor roles in the integration process to bacterial T-DNA-associated proteins, which likely function as molecular links between the T-DNA and host factors. For example, initially VirD2 was thought to act as an integrase or a ligase (Pansegrau et al., 1993; Tinland et al., 1995). However, later studies have shown that host factors, but not VirD2, mediate T-DNA ligation in an in vitro system (Ziemienowicz et al., 2000), whereas any role that VirD2 might play in integration would be by recruiting these host factors.

Additional evidence for the involvement of cellular factors in TDNA integration derives from the use of Saccharomyces cerevisiae as a heterologous host for Agrobacterium (Bundock et al., 1995). In yeast, foreign DNA integration can occur either by non-homologous end joining (NHEJ) or by homologous recombination (HR), depending on the presence in the integrating DNA of sequences homologous to a target sequence in the yeast genome. By using yeast mutants impaired in either in HR or in NHEJ machinery, it is possible to direct T-DNA integration toward one of those pathways (Van Attikum et al., 2001; Van Attikum and Hooykaas, 2003). The involvement of specific host proteins in each of these T-DNA integration pathways was demonstrated. For HR, two host proteins
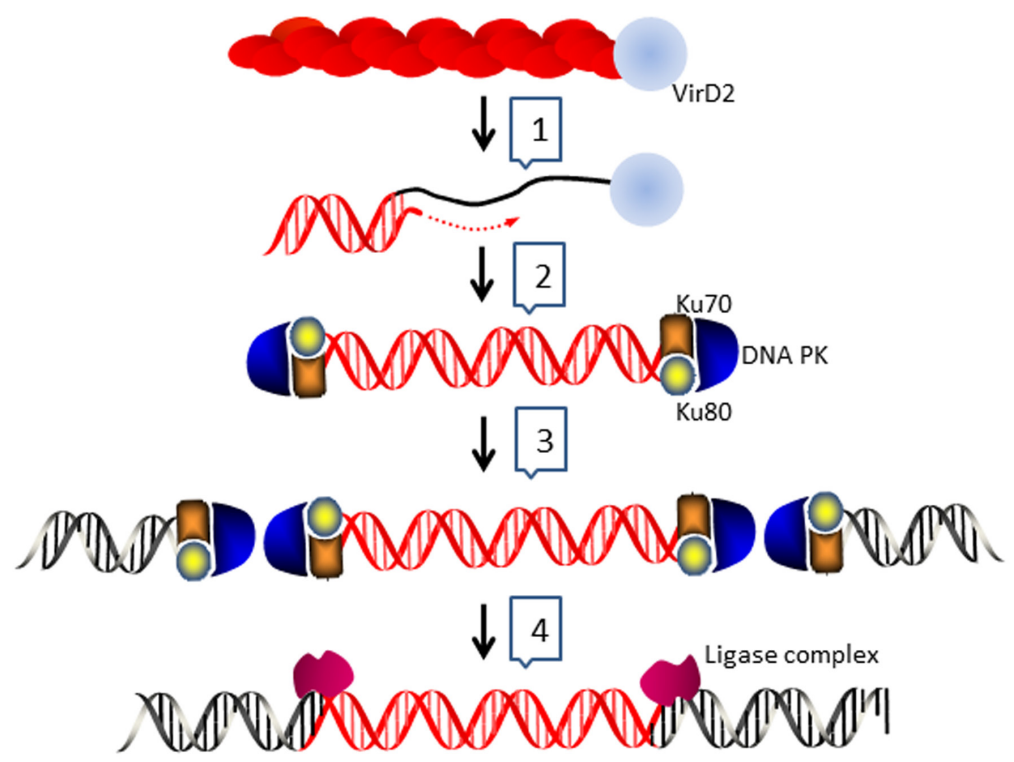

Fig. 4. Model of transferred DNA (T-DNA) integration in host cell chromatin. The T-complex is uncoated from its associated proteins (1), and converted to a double-stranded form that associates with host DNA repair machinery components, such as DNA PK, Ku70 and Ku80 (2). It then interacts with a double strand break (DSB) in the host DNA (3), and is integrated into the host genome by a host ligase activity (4). were required: Rad52, an ssDNA-binding protein, and Rad51 involved in homologous DNA pairing and strand exchange reaction (Van Attikum and Hooykaas, 2003). For NHEJ, the following host proteins were necessary: Ku70, a double-stranded DNA-binding protein that functions in heterodimer with Ku80, and Mre11, which functions in complex with Rad50 and Xrs2 and has an exonuclease activity, Sir4, and Lig4, a DNA ligase (Van Attikum et al., 2001). In a double mutant disrupted in Rad52 and Ku70, the two key genes in the HR and NHEJ pathways, respectively, no T-DNA integration at all was observed (Van Attikum and Hooykaas, 2003).

How the requirements for T-DNA integration in yeast compare to integration in plants, the natural Agrobacterium hosts? In higher plants, NHEJ is the main pathway of foreign DNA integration (Fig. 4), whereas HR occurs only at very low rates (Gheysen et al., 1991; Mayerhofer et al., 1991). Several studies involving plant mutants in genes of the HR and NHEJ pathways have supported their overall role in T-DNA integration, although the specific results were sometimes difficult to interpret. In Arabidopsis, AtLig4 and AtKu80 were reported to be required for T-DNA integration in two studies (Friesner and Britt, 2003; Li et al., 2005b), but found to be dispensable for integration in another study (Gallego et al., 2003). These discrepancies might originate in the different techniques used for transformation, i.e., floral-dipping versus root tissue regeneration, or reflect more complex and redundant pathways for $\mathrm{HR}$ and NHEJ in plants. In addition, a mutant in the AtRAD5 gene, closely related to the yeast $R A D 51$ gene involved in HR, displayed a reduced susceptibility to Agrobacterium infection (Sonti et al., 1995). In rice, plant lines down-regulated in Ku70, Ku80, and Lig4 all showed strongly reduced rates of overall T-DNA integration; interestingly, the rate of HR integration was relatively increased in these three mutant rice lines (Nishizawa-Yokoi et al., 2012). The T-DNA integration pathway in plants can also be manipulated by ectopic expression of the components of the HR pathway. For example, transgenic Arabidopsis expressing the yeast $R A D 54$ displayed a significant increase in frequency of $\mathrm{T}$ DNA integration by HR (Shaked et al., 2005). Intriguingly, a recent study reported that down-regulation of $X R C C 4$, a major component of the NHR pathway, in Arabidopsis and Nicotiana benthamiana, resulted in increased rates of $\mathrm{T}$ DNA integration, whereas the opposite effect was observed in plants overexpressing XRCC4 (Vaghchhipawala et al., 2012). The same study also reported interaction between XRCC4 and the Agrobacterium VirE2 protein, which was suggested to prevent efficient DSB repair in order to increase the probability for the T-DNA to be targeted to unrepaired DSBs (Vaghchhipawala et al., 2012).

Besides DNA repair machinery, host proteins that are mainly involved in chromatin structure or remodeling are important for T-DNA integration. Core histones, particularly $\mathrm{H} 2 \mathrm{~A}$, are required for efficient $\mathrm{T}$-DNA integration in the host genome (Mysore et al., 2000; Yi et al., 2002), which may be linked to the ability of VIP1 to bridge between histones and the T-complex during chromatin targeting (see above) (Lacroix et al., 2008; Li et al., 2005a; Loyter et al., 2005). Also, Arabidopsis mutants deficient in chromatin assembly factor 1 (CAF-1) were more sensitive to stable transformation by Agrobacterium than the wild-type plants (Endo et al., 2006); CAF-1 is involved in chromatin remodeling, and might represent a factor limiting T-DNA integration. 
Interestingly, the relative frequency of T-DNA integration by HR was higher in CAF-1 deficient plants (Endo et al., 2006). Finally, VIP2 is also involved in T-DNA integration, potentially by regulating histone gene transcription (see above) (Anand et al., 2007).

Another important question in regard to the mechanism(s) of T-DNA integration is whether the invading T-strand is converted to a double stranded form before or after the integration event. One of the early models for T-DNA integration, termed single-stranded gap repair (SSGR), postulated that T-DNA integration begins with annealing of the T-strand RB to the host genomic DNA via microhomologies, followed by synthesis of the second strand and ligation of T-DNA LB (Tinland, 1996). Subsequent studies have challenged this model (Tzfira et al., 2004a). The analysis of a larger number of T-DNA integration sites has revealed integration patterns incompatible with the SSGR model: microhomologies are not consistently observed at the integration sites (Alonso et al., 2003), and SSGR cannot explain some of the complex integration patterns with multiple T-DNAs in direct or reverse orientation with or without filler DNA. Specifically, the occurrence of two T-DNA molecules integrated in the head-to-head configuration is not compatible with the SSGR model because head-to-head recombination is not possible for single-stranded DNA. Similarly, the SSGR model cannot explain the presence of filler DNA (Tzfira et al., 2004a). Instead, several lines of evidence indicate that the T-strand is converted into a double-stranded form before integration. The generation of DSBs using a rare cutting endonuclease resulted in increased frequency of foreign DNAintegration after Agrobacterium-mediated transformation (Salomon and Puchta, 1998), consistent with the higher frequency of transgene integration after X-ray treatment, known to induce DSBs (Leskov et al., 2001). These observations suggested that T-DNA likely integrates into DSBs in a doublestranded form. The direct proof of this notion was supplied a few years later by using rare cutting endonuclease sites in both the host genome and the T-DNA (Chilton and Que, 2003; Tzfira et al., 2003). Analyses of integration sites of T-DNA molecules exposed in vivo to a transiently expressed rare-cutting endonuclease revealed precise reconstitution after ligation of the original restriction site at the junction between the T-DNA and the host DNA, which had been also digested by the same enzyme. This is possible only if the T-strand has been converted to a double-stranded form before integration, because the endonucleases used in these studies can cleave only double-stranded DNA (Chilton and Que, 2003; Tzfira et al., 2003). Obviously, it cannot be excluded that several pathways for T-DNA integration coexist, but most of the recent data advocate for integration in a double stranded form generated from the Tstrand molecule by the host DNA repair machinery. Major findings described in this section are summarized in a simple model for T-DNA integration presented in Fig. 4.

\section{Regulation of Transferred-DNA expression and plant resistance to Agrobacterium}

T-DNA expression is regulated by various host factors that affect the activity of the promoters of genes naturally present within the wild type T-DNA. For example, the nopaline synthase promoter responds positively to wound auxin induction (An et al., 1990), and the promoter of the Atu6002 gene is activated when cell division is induced, such as during the tumor growth (Lacroix and Citovsky, unpublished data). There is long-known, yet still poorly understood, variability in susceptibility to Agrobacterium-mediated genetic transformation not only between plant species, but also between different tissues and different physiological conditions of the host. For example, different ecotypes of Arabidopsis have different levels of susceptibility, and pre-treatment with growth regulators also modifies the susceptibility of a given tissue (Chateau et al., 2000). This variability likely reflects the ability of the host plant to mount a defense reaction and/or to restrict the T-DNA transfer and gene expression, as well as the ability of Agrobacterium to escape host defense mechanisms and/or to subvert them for enhancement of its infectivity.

Traditionally, T-DNA expression is classified into two modes: transient and stable. Transient expression is a phenomenon usually defined as a peak in T-DNA expression that occurs early, within 2-4 days, after transformation (Janssen and Gardner, 1990; Nam et al., 1999; Narasimhulu et al., 1996), and which then is decreased, both in terms of the number of expressing cells and in the expression levels per transformed cell. In contrast, late gene expression, which occurs 10-14 days after infection (Janssen and Gardner, 1990), is stable-and inheritable in the case of germline transformation (Bent, 2006) - resulting from the integrated T-DNA.

Several mechanisms likely account for the duration and levels of T-DNA expression. First, transient expression likely occurs from the T-DNA molecules that have not yet integrated into the host genome; the inherent instability of such unintegrated T-DNA would limit the duration of its expression. Indeed, T-DNAgene expression can be detected very early after inoculation, presumably before integration (Narasimhulu et al., 1996). Consistent with this notion, several plant mutants with reduced tumor formation still display normal levels of transient T-DNA expression (Li et al., 2005b; Nam et al., 1999; Zhu et al., 2003b), indicating that transient and stable expression can be uncoupled and that transient expression does not require the integration event. Furthermore, even in plant hosts that support T-DNA integration, expression of non-integrated T-DNA could be demonstrated directly by co-transformation with two T-DNAs: the C-T-DNA with the Cre recombinase expression cassette, and the K-T-DNA with the nptll expression cassette and GUS expression cassette flanked by two lox sites. These experiments generated transgenic plants that contained integrated Cre-processed K-T-DNA, indicating expression of the C-T-DNA, yet did not contain integrated copies of C-T-DNA (De Buck et al., 2000). Recent intriguing data suggest that T-DNA transient expression may involve not just individual unintegrated molecules, but more complex extra-chromosomal structures composed of these molecules and generated after Agrobacterium infection (Singer et al., 2012), which may be involved in usually high level of transient expression.

In addition, the expression levels of integratedT-DNAare affected by different host-related factors. Mechanisms that limit expression of integrated T-DNA include death of some of the initially transformed cells (this mechanism is especially important for tumor formation or for systems involving plant regeneration from transformed cells via a callus stage), and loss of the integrated sequences due to intra-genomic reorganization. The host RNA silencing defense, however, represents the major negative regulator of T-DNAexpression, both transient and stable.

RNA silencing represents a plant defense response against attack of foreign genetic material, particularly against viruses (Ding and Voinnet, 2007; Hooykaas, 1994). Silencing mechanisms are 
also involved in the host defense against Agrobacterium infection; specifically, small interfering RNAs (siRNAs) specific for the T-DNA sequence are generated by the host plant during Agrobacterium infection (Dunoyer et al., 2006), and plants deficient in siRNA pathways are hypersusceptible to Agrobacterium. Conversely, the miRNA pathway seems to be required for disease development (Dunoyer et al., 2006). This silencing response to the invading bacterial DNA likely contributes to the limited and relatively early timing of high levels of transient T-DNA expression observed in most transformations experiments: this time period may be required for the host to mount the defense reaction, after which RNA silencing takes effect, leading to reduction in T-DNA gene expression. Supporting this idea, expression of RNAsilencing suppressors encoded by diverse plant viruses, such as $\mathrm{P} 19$ of Tomato bushy stunt virus, HcPro of Potato virus Y, or V2 of Tomato yellow leaf curl virus, during Agrobacterium infection, significantly increased the level and duration of transient T-DNA expression (Voinnet et al., 2003; Zrachya et al., 2007). Although, by analogy to plant viruses most of which encode silencing suppressors (Qu and Morris, 2005), evolution of an RNA silencing suppressor in Agrobacterium would make biological sense, such suppressor has not been identified to date. While a decrease of siRNAs corresponding to the T-DNA sequences levels was observed in developing tumors, it was attributed to modifications in hormonal status of tumor tissues, rather than to a putative Agrobacterium silencing suppressor (Dunoyer et al., 2006).

Another mechanism regulating T-DNA expression may be DNA methylation, which is often observed in integrated transgenes, particularly when several T-DNA copies are integrated in the host genome (Gelvin et al., 1983; Hepburn et al., 1983). A recent study described genome-wide changes in the extent of DNA methylation in crown gall tumors as compared to mock-inoculated tissues (Gohlke et al., 2013). However, these changes may be not directly linked to Agrobacterium infection and/or genetic transformation, but represent indirect effects of global changes in the activity of plant growth regulators that induce cell division and tumor formation. Indeed, directing plant cell cultures to different developmental pathways by addition of plant growth regulators results in major modifications of DNA methylation as well as in other epigenetic modifications (Miguel and Marum, 2011).

Although Agrobacterium usually does not trigger extensive visible symptoms of plant hypersensitive defense reaction, such as necrosis, studies of changes in the host transcriptional activity induced by Agrobacterium infection have shown that related defense reaction mechanisms are activated. In Arabidopsis cells, many genes known to be involved in plant defense response are activated 48 hours after inoculation with Agrobacterium as compared to mockinoculated cells (Ditt et al., 2006). A kinetic study of expression of several of these genes during the infection process revealed that the initial induction was followed by a decrease in expression levels (Veena et al., 2003), suggesting that these defense genes may be suppressed by as yet unknown Agrobacterium factors. In addition, an Arabidopsis mutant in the EFR gene, encoding a cell surface receptor that activates the basal defense pathway in response to pathogen-associated molecular patterns (PAMPs), such as EF-Tu, displayed hyper-susceptibility to Agrobacterium (Zipfel et al., 2006). Thus, the ability of Arabidopsis to detect bacterial pathogens and trigger the basal defense response pathway confers a measure of resistance to Agrobacterium infection. Production of salicylic acid (SA), the hallmark of the systemic acquired resistance (SAR) pathway, by the infected plant has also been shown to attenuate its susceptibility to Agrobacterium (Anand et al., 2008; Yuan et al., 2007). This ability of Agrobacterium to induce SAR, however, may depend on the host species, tissues, or the inoculation method. For example, Agrobacterium co-incubated with Arabidopsis seedlings modulated SAR by reducing SA accumulation and transcript levels of pathogenesis-related genes PR-1 and PR-5 (Gaspar et al., 2004). Predictably, this repression of SAR by Agrobacterium requires bacterial attachment to the host cell; when the attachment was compromised in a rat1 Arabidopsis mutant defective for the lysine-rich arabinogalactan protein, AtAGP17, the plants became resistant to Agrobacterium and did not display reduced expression of $P R-1$ and $P R-5$ upon infection (Gaspar et al., 2004). Unlike Arabidopsis, tobacco plants inoculated with Agrobacterium by leaf infiltration exhibited increased expression of the $P R$ - 1 gene (Pruss et al., 2008), at levels sufficient to elicit resistance to Tobacco mosaic virus (TMV). This induction of $P R-1$ expression was not dependent on the presence of the Ti-plasmid, likely representing a non-specific host response to bacterial challenge. The micro-RNA miR393, that represses auxin signaling and promotes antibacterial resistance, was also elevated following Agrobacterium infection of tobacco (Pruss et al., 2008). However, unlike PR-1, miR393 was induced only by Agrobacterium harboring a Ti-plasmid, suggesting a host cell reaction to the transfer of foreign genetic material and/or proteins.

\section{"Arms race" in Agrobacterium-plant interactions}

Host-pathogen interactions often represent an "arms race", in which the host attempts to ward off invaders while the pathogen strives to suppress the host's defense and even subvert it for the benefit of infection. This strategy of taking advantage of the host defense/stress response pathways is employed by Agrobacterium for genetic transformation of plant cells. First, Agrobacteriumutilizes plant phenolics - a class of chemical compounds which includes antibacterial substances, phytoalexins, normally produced during defense response-as signals that induce the bacterial vir genes and activate the virulence system. Agrobacterium also subverts a defensive host MAP kinase signaling pathway to facilitate nuclear import and chromatin targeting of its T-complexes. Specifically, the host plant responds to Agrobacterium infection by inducing MPK3 that directly phosphorylates VIP1 and activates its nuclear import (Djamei et al., 2007), which in turn facilitates nuclear import of the T-complex (Tzfira et al., 2001), whereas nuclear VIP1 then facilitates intranuclear transport of the T-complex to the target chromatin (Lacroix et al., 2008). Interestingly, an Arabidopsis mutant in basal immune response inhibitor WRKY17 displays increased levels of VIP1 transcription and is more susceptible to Agrobacterium than the wild-type plant (Lacroix, 2013b). Further, Agrobacterium infection also induces expression of the host F-box protein VBF which it is thought to utilize for proteasomal disassembly of the T-complex (Zaltsman et al., 2010b) and exposure of the T-strand (Zaltsman et al., 2013) before integration. Finally, Agrobacterium most likely integrates its T-DNA into DSBs by taking advantage of the host DNA repair machinery (Chilton and Que, 2003; Leskov et al., 2001; Salomon and Puchta, 1998; Tzfira et al., 2003; Tzfira et al., 2004a), which may also be considered a defense response of the cell to DNA damage. 


\section{Significance}

Understanding the complex interplay between the bacterium and its host is crucial for future improvement of Agrobacterium's uses in biotechnology. Indeed, the efficiency of transformation remains low for many economically-important plant species, and elucidating the function of host factors affecting T-DNA transfer and integration will help to improve transformation methods. Moreover, the Agrobacterium-host plant interaction has been a remarkably useful experimental system to help understand many basic cellular processes, such as cell-cell recognition, macromolecule transport, and DNA repair and integration.

\section{Acknowledgements}

We apologize to colleagues whose original work was not cited due to lack of space. The work in our laboratory is supported by grants from $\mathrm{NIH}$, NSF, USDA/NIFA, BARD and BSF to V.C.

\section{References}

ABU-ARISHA, FRENKIEL-KRISPIN D, FRICKE T, TZFIRA T, CITOVSKY V, WOLF S G, ELBAUM M (2004). Three-dimensional reconstruction of Agrobacterium VirE2 protein with single-stranded DNA. J Biol Chem 279: 25359-25363.

ALONSO J M, STEPANOVAAN, LEISSE T J, KIM C J, CHEN H, SHINN P, STEVENSON D K, ZIMMERMAN J, BARAJAS P, CHEUK R, et al. (2003). Genome-wide insertional mutagenesis of Arabidopsis Thaliana. Science 301: 653-657.

ALY K A, BARON C (2007). The VirB5 protein localizes to the T-pilus tips in Agrobacterium tumefaciens. Microbiology 153: 3766-3775.

AN G, COSTA M A, HA S B (1990). Nopaline synthase promoter is wound inducible and auxin inducible. Plant Cell 2: 225-233.

ANAND A, KRICHEVSKY A, SCHORNACK S, LAHAYE T, TZFIRA T, TANG Y, ClTOVSKY V, MYSORE KS (2007). Arabidopsis VIRE2 INTERACTING PROTEIN2 is required for Agrobacterium T-DNAintegration in plants. Plant Cell19: 1695-1708.

ANAND A, UPPALAPATI S R, RYU C M, ALLEN S N, KANG L, TANG Y, MYSORE $\mathrm{K} S$ (2008). Salicylic acid and systemic acquired resistance play a role in attenuating crown gall disease caused by Agrobacterium tumefaciens. Plant Physiol 146: 703-715

ANKENBAUERR G, NESTEREW (1990). Sugar-mediated induction of Agrobacterium tumefaciens virulence genes: structural specificity and activities of monosaccharides. J Bacteriol 172: 6442-6446.

BACKERTS, FRONZESR, WAKSMANG (2008). VirB2 and VirB5 proteins: specialized adhesins in bacterial type-IV secretion systems? Trends Microbiol 16: 409-413.

BAKO L, UMEDA M, TIBURCIO A F, SCHELL J, KONCZ C (2003). The VirD2 pilot protein of Agrobacterium-transferred DNA interacts with the TATA box-binding protein and a nuclear protein kinase in plants. Proc Natl Acad Sci USA 100: 10108-10113.

BALLAS N, CITOVSKY V (1997). Nuclear localization signal binding protein from Arabidopsis mediates nuclear import of Agrobacterium VirD2 protein. Proc Natl Acad Sci USA 94: 10723-10728.

BENT A (2006). Arabidopsis Thaliana floral dip transformation method. Methods Mol Biol 343: 87-103.

BHATTACHARJEE S, LEELY, OLTMANNS H, CAOH, VEENA, CUPERUS J, GELVIN S B (2008). IMPa-4, an Arabidopsis importin alpha isoform, is preferentially involved in Agrobacterium-mediated plant transformation. Plant Cell20: 2661-2680.

BOLTON G W, NESTER E W, GORDON M P (1986). Plant phenolic compounds induce expression of the Agrobacterium tumefaciens loci needed for virulence. Science 232: 983-985.

BRENCIC A, WINANS S C (2005). Detection of and response to signals involved in host-microbe interactions by plant-associated bacteria. Microbiol Mol Biol Rev 69: 155-194.

BUNDOCK P, DEN DULK-RAS A, BEIJERSBERGEN A, HOOYKAAS P J (1995). Trans-kingdom T-DNAtransfer from Agrobacterium tumefaciensto Saccharomyces cerevisiae. EMBO J 14: 3206-3214.

CANGELOSI G A, ANKENBAUER R G, NESTER E W (1990). Sugars induce the
Agrobacterium virulence genes through a periplasmic binding protein and a transmembrane signal protein. Proc Natl Acad Sci USA 87: 6708-6712.

CANGELOSI GA, MARTINETTI G, LEIGH J A, LEE C C, THEINES C, NESTER E W (1989). Role for Agrobacterium tumefaciens ChvA protein in export of beta-1,2glucan. J Bacteriol 171: 1609-1615.

CARDOZO T, PAGANO M (2004). The SCF ubiquitin ligase: insights into a molecular machine. Nat Rev Mol Cell Biol 5: 739-751.

CASCALES E, CHRISTIE P J (2004). Definition of a bacterial type IV secretion pathway for a DNA substrate. Science 304: 1170-1173.

CHANG C H, ZHU J, WINANS S C (1996). Pleiotropic phenotypes caused by genetic ablation of the receiver module of the Agrobacterium tumefaciens VirA protein. $J$ Bacteriol 178: 4710-4716.

CHARLES T C, NESTER E W (1993). A chromosomally encoded two-component sensory transduction system is required for virulence of Agrobacterium tumefaciens. J Bacteriol 175: 6614-6625.

CHATEAU S, SANGWAN R S, SANGWAN-NORREEL B S (2000). Competence of Arabidopsis Thaliana genotypes and mutants for Agrobacterium tumefaciensmediated gene transfer: role of phytohormones. J Exp Bot 51: 1961-1968.

CHEN S, JIN W, WANG M, ZHANG F, ZHOU J, JIA Q, WU Y, LIU F, WU P (2003). Distribution and characterization of over 1000 T-DNA tags in rice genome. Plant J36: 105-113.

CHILTON M D, QUE Q (2003). Targeted integration of T-DNAinto the tobacco genome at double-stranded breaks: new insights on the mechanism of T-DNA integration. Plant Physiol 133: 956-965.

CHRISTIE P J (2004). Type IV secretion: the Agrobacterium VirB/D4 and related conjugation systems. Biochim Biophys Acta 1694: 219-234.

CITOVSKY V, GURALNICK B, SIMON M N, WALL J S (1997). The molecular structure of Agrobacterium VirE2-single stranded DNA complexes involved in nuclear import. J Mol Biol 271: 718-727.

CITOVSKY V, KAPELNIKOV A, OLIEL S, ZAKAI N, ROJAS M R, GILBERTSON R L, TZFIRA T, LOYTERA (2004). Protein interactions involved in nuclear import of the Agrobacterium VirE2 protein in vivo and in vitro. J Biol Chem 279: 29528-29533.

CITOVSKY V, WONG M L, ZAMBRYSKI P (1989). Cooperative interaction of Agrobacterium VirE2 protein with single-stranded DNA: implications for the T-DNA transfer process. Proc Natl Acad Sci USA 86: 1193-1197.

CITOVSKY V, ZUPAN J, WARNICK D,ZAMBRYSKI P (1992). Nuclear localization of Agrobacterium VirE2 protein in plant cells. Science 256: 1802-1805.

CLAUCE-COUPEL H, CHATEAU S, DUCROCQ C, NIOT V, KAVERI S, DUBOIS F, SANGWAN-NORREEL B, SANGWAN R S (2008). Role of vitronectin-like protein in Agrobacterium attachment and transformation of Arabidopsis cells. Protoplasma 234: 65-75.

COLCOMBET J, HIRT H (2008). Arabidopsis MAPKs: a complex signalling network involved in multiple biological processes. Biochem J 413: 217-226.

DANHORN T, FUQUAC (2007). Biofilm formation by plant-associated bacteria. Annu Rev Microbiol 61: 401-422.

DE BUCK S, DE WILDE C, VAN MONTAGU M, DEPICKER A (2000). Determination of the T-DNA transfer and the T-DNA integration frequencies upon cocultivation of Arabidopsis Thaliana root explants. Mol Plant Microbe Interact 13: 658-665.

DE CLEENE M, DE LEY J (1976). The host range of crown gall. Bot. Rev. 42: 389-466.

DE GROOT M J, BUNDOCK P, HOOYKAAS P J, BEIJERSBERGEN A G (1998). Agrobacterium tumefaciens-mediated transformation of filamentous fungi. Nat Biotechnol 16: 839-842.

DE IANNINO N I, UGALDE R A (1989). Biochemical characterization of avirulent Agrobacterium tumefaciens chvA mutants: synthesis and excretion of beta-(1-2) glucan. J Bacteriol 171: 2842-2849.

DENG W, CHEN L, WOOD D W, METCALFE T, LIANG X, GORDON M P, COMAI L, NESTER E W (1998). Agrobacterium VirD2 protein interacts with plant host cyclophilins. Proc Natl Acad Sci USA 95: 7040-7045.

DING S W, VOINNET O (2007). Antiviral immunity directed by small RNAs. Cell 130: 413-426.

DITT R F, KERR K F, DE FIGUEIREDO P, DELROW J, COMAI L, NESTER E W (2006). The Arabidopsis Thaliana transcriptome in response to Agrobacterium tumefaciens. Mol Plant Microbe Interact 19: 665-681.

DJAMEI A, PITZSCHKE A, NAKAGAMI H, RAJH I, HIRT H (2007). Trojan horse strategy in Agrobacterium transformation: abusing MAPK defense signaling. 
Science 318: 453-456.

DODDING M P, WAY M (2011). Coupling viruses to dynein and kinesin-1. EMBO J 30: 3527-3539.

DOMINGUEZA, FAGOAGAC, NAVARROL, MORENOP, PENAL(2002). Regeneration of transgenic citrus plants under non selective conditions results in high-frequency recovery of plants with silenced transgenes. Mol Genet Genomics 267: 544-556.

DUMAS F, DUCKELY M, PELCZAR P, VAN GELDER P, HOHN B (2001). An Agrobacterium VirE2 channel for transferred-DNA transport into plant cells. Proc Natl Acad Sci USA 98: 485-490.

DUNOYER P, HIMBER C, VOINNET O (2006). Induction, suppression and requirement of RNA silencing pathways in virulent Agrobacterium tumefaciens infections. Nat Genet 38: 258-263.

DYM O, ALBECK S, UNGER T, JACOBOVITCH J, BRANZBURG A, MICHAEL Y, FRENKIEL-KRISPIN D, WOLF S G, ELBAUM M (2008). Crystal structure of the Agrobacterium virulence complex VirE1-VirE2 reveals a flexible protein that can accommodate different partners. Proc Natl Acad Sci USA 105: 11170-11175.

ENDO M, ISHIKAWA Y, OSAKABE K, NAKAYAMAS, KAYAH, ARAKIT, SHIBAHARA $\mathrm{K}$, ABE K, ICHIKAWA H, VALENTINE L, HOHN B, TOKI S (2006). Increased frequency of homologous recombination and T-DNA integration in Arabidopsis CAF-1 mutants. EMBO J 25: 5579-5590.

ESCOBAR M A, DANDEKAR A M (2003). Agrobacterium tumefaciens as an agent of disease. Trends Plant Sci 8: 380-386.

FORBES D J (1992). Structure and function of the nuclear pore complex. Annu Rev Cell Biol 8: 495-527.

FRASER C M, CHAPPLE C (2011). The phenylpropanoid pathway in Arabidopsis. Arabidopsis Book 9: e0152.

FRIESNER J, BRITT A B (2003). Ku80- and DNA ligase IV-deficient plants are sensitive to ionizing radiation and defective in T-DNA integration. Plant J 34: 427-440.

FRIESNER J D, LIU B, CULLIGAN K, BRITTAB (2005). lonizing radiation-dependent gamma-H2AX focus formation requires ataxia telangiectasia mutated and ataxia telangiectasia mutated and Rad3-related. Mol Biol Cell 16: 2566-2576.

GALLEGO M E, BLEUYARD J Y, DAOUDAL-COTTERELL S, JALLUT N, WHITE C $I$ (2003). Ku80 plays a role in non-homologous recombination but is not required for T-DNA integration in Arabidopsis. Plant J 35: 557-565.

GAO R, LYNN D G (2005). Environmental pH sensing: resolving the VirA/VirG two-component system inputs for Agrobacterium pathogenesis. J Bacteriol 187: 2182-2189.

GARCIA-RODRIGUEZ F M, SCHRAMMEIJER B, HOOYKAAS P J (2006). The Agrobacterium VirE3 effector protein: a potential plant transcriptional activator. Nucleic Acids Res 34: 6496-6504.

GASPAR Y M, NAM J, SCHULTZ C J, LEE L Y, GILSON P R, GELVIN S B, BACIC $A$ (2004). Characterization of the Arabidopsis lysine-rich arabinogalactan-protein AtAGP17 mutant (rat1) that results in a decreased efficiency of Agrobacterium transformation. Plant Physiol 135: 2162-2171.

GELVIN S B (1998). Agrobacterium VirE2 proteins can form a complex with T strands in the plant cytoplasm. J Bacteriol 180: 4300-4302.

GELVIN SB (2003). Agrobacterium-mediated plant transformation: the biology behind the "gene-jockeying" tool. Microbiol Mol Biol Rev 67: 16-37.

GELVIN S B (2010). Plant proteins involved in Agrobacterium-mediated genetic transformation. Annu Rev Phytopathol 48: 45-68.

GELVIN S B, KARCHER S J, DIRITA V J (1983). Methylation of the T-DNA in Agrobacterium tumefaciens and in several crown gall tumors. NucleicAcids Res 11:159-174.

GHEYSEN G, VILLARROEL R, VAN MONTAGU M (1991). Illegitimate recombination in plants: a model for T-DNA integration. Genes Dev 5: 287-297.

GOHLKE J, SCHOLZ C J, KNEITZ S, WEBER D, FUCHS J, HEDRICH R, DEEKEN $R$ (2013). DNA methylation mediated control of gene expression is critical for development of crown gall tumors. PLoS Genet 9: e1003267.

GRAFI G, FLORENTIN A, RANSBOTYN V, MORGENSTERN Y (2011). The stem cell state in plant development and in response to stress. Front Plant Sci 2: 53.

GRANGE W, DUCKELY M, HUSALE S, JACOB S, ENGEL A, HEGNER M (2008). VirE2: a unique ssDNA-compacting molecular machine. PLoS Biol 6: e44.

HAMILTON C M, FRARY A, LEWIS C, TANKSLEY S D (1996). Stable transfer of intact high molecular weight DNA into plant chromosomes. Proc Natl Acad Sci USA 93: 9975-9979.
HEPBURN A G, CLARKE L E, PEARSON L, WHITE J (1983). The role of cytosine methylation in the control of nopaline synthase gene expression in a plant tumor. J Mol Appl Genet 2: 315-329.

HERRERA-ESTRELLA A, VAN MONTAGU M, WANG K (1990). A bacterial peptide acting as a plant nuclear targeting signal: the amino-terminal portion of Agrobacterium VirD2 protein directs a beta-galactosidase fusion protein into tobacco nuclei. Proc Natl Acad Sci USA 87: 9534-9537.

HIROOKA T, KADO C I (1986). Location of the right boundary of the virulence region on Agrobacterium tumefaciens plasmid pTiC58 and a host-specifying gene next to the boundary. $J$ Bacteriol 168: 237-243.

HIRSCH A M (1999). Role of lectins (and rhizobial exopolysaccharides) in legume nodulation. Curr Opin Plant Biol 2: 320-326.

HO M S, TSAI P I, CHIEN C T (2006). F-box proteins: the key to protein degradation. J Biomed Sci 13: 181-191.

HOOYKAAS P J, BEIJERSBERGEN A G M (1994). The virulence system of Agrobacterium tumefaciens. Annu Rev Phytopathol 32: 157-179.

HOWARD E A, ZUPAN J R, CITOVSKY V, ZAMBRYSKI P C (1992). The VirD2 protein of $A$. tumefaciens contains a $\mathrm{C}$-terminal bipartite nuclear localization signal: implications for nuclear uptake of DNA in plant cells. Cell 68: 109-118.

HWANG H H, GELVIN S B (2004). Plant proteins that interact with VirB2, the Agrobacterium tumefaciens pilin protein, mediate plant transformation. Plant Cell 16: 3148-3167.

JANSSEN B J, GARDNER R C (1990). Localized transient expression of GUS in leaf discs following cocultivation with Agrobacterium. Plant Mol Biol 14: 61-72.

JOUBERT P, BEAUPERE D, WADOUACHI A, CHATEAU S, SANGWAN R S, SANGWAN-NORREELBS (2004). Effect of phenolic glycosides on Agrobacterium tumefaciens virHgene induction and plant transformation. J Nat Prod67: 348-351.

$\mathrm{KADO} \mathrm{CI}(2000)$. The role of the T-pilus in horizontal gene transfer and tumorigenesis. Curr Opin Microbiol 3: 643-648.

KIM S I, VEENA V, GELVIN S B (2007). Genome-wide analysis of Agrobacterium TDNA integration sites in the Arabidopsis genome generated under non-selective conditions. Plant J 51: 779-791.

KLEE H J, WHITE F F, IYER V N, GORDON M P, NESTER E W (1983). Mutational analysis of the virulence region of an Agrobacterium tumefaciens Ti plasmid. $J$ Bacteriol 153: 878-883.

KUNIK T, TZFIRA T, KAPULNIK Y, GAFNI Y, DINGWALL C,CITOVSKY V (2001). Genetic transformation of HeLa cells by Agrobacterium. Proc Natl Acad Sci USA 98: 1871-1876.

LACROIX B, CITOVSKY V (2011). Extracellular VirB5 enhances T-DNA transfer from Agrobacterium to the host plant. PLoS One 6: e25578.

LACROIX B, LOYTER A, CITOVSKY V (2008). Association of the Agrobacterium T-DNA-protein complex with plant nucleosomes. Proc Natl Acad Sci USA 105: 15429-15434

LACROIX B, TZFIRA T, VAINSTEIN A, CITOVSKY V (2006). A case of promiscuity: Agrobacterium's endless hunt for new partners. Trends Genet 22: 29-37.

LACROIX B, VAIDYA M, TZFIRA T, CITOVSKY V (2005). The VirE3 protein of Agrobacterium mimics a host cell function required for plant genetic transformation. EMBO J 24: 428-437.

LACROIX B, CITOVSKY V (2013a). Crown Gall Tumors. In: S.H. Maloy, K. (ed) Brenner's Online Encyclopedia of Genetics, 2nd edition. Academic Press.

LACROIX B, CITOVSKY V (2013b). A mutation in negative regulator of basal resistance WRKY17 of Arabidopsisincreases susceptibility to Agrobacterium-mediated transient genetic transformation. F1000Research 2: 33.

LECHNER E, ACHARD P, VANSIRI A, POTUSCHAK T, GENSCHIK P (2006). F-box proteins everywhere. Curr Opin Plant Biol 9: 631-638.

LEE K, DUDLEY M W, HESS K M, LYNN D G, JOERGER R D, BINNS A N (1992). Mechanism of activation of Agrobacterium virulence genes: identification of phenol-binding proteins. Proc Natl Acad Sci USA 89: 8666-8670.

LEE Y W, JIN S, SIM W S, NESTER E W (1995). Genetic evidence for direct sensing of phenolic compounds by the VirA protein of Agrobacterium tumefaciens. Proc Natl Acad Sci USA 92: 12245-12249.

LESKOV K S, CRISWELL T, ANTONIO S, LI J, YANG C R, KINSELLA T J, BOOTHMAN D A (2001). When X-ray-inducible proteins meet DNA double strand break repair. Semin Radiat Oncol 11: 352-372. 
LI J, KRICHEVSKY A, VAIDYA M, TZFIRA T, CITOVSKY V (2005a). Uncoupling of the functions of the Arabidopsis VIP1 protein in transient and stable plant genetic transformation by Agrobacterium. Proc Natl Acad Sci USA 102: 5733-5738.

LI J, VAIDYA M, WHITE C, VAINSTEIN A, CITOVSKY V, TZFIRA T (2005b). Involvement of KU80 in T-DNA integration in plant cells. Proc Natl Acad Sci USA 102: 19231-19236.

LIU P, NESTER E W (2006). Indoleacetic acid, a product of transferred DNA, inhibits vir gene expression and growth of Agrobacterium tumefaciens C58. Proc Natl Acad Sci USA 103: 4658-4662.

LLOSAM, GOMIS-RUTH FX, COLL M, DE LA CRUZ FD F (2002). Bacterial conjugation: a two-step mechanism for DNA transport. Mol Microbiol 45: 1-8.

LOYTER A, ROSENBLUH J, ZAKAI N, LI J, KOZLOVSKY S V, TZFIRA T, CITOVSKY $\mathrm{V}$ (2005). The plant VirE2 interacting protein 1. a molecular link between the Agrobacterium T-complex and the host cell chromatin? Plant Physiol 138: 1318-1321.

MAGORI S, CITOVSKY V (2011). Agrobacterium counteracts host-induced degradation of its effector F-box protein. Sci Signal 4: ra69.

MATTHYSSE A G (1983). Role of bacterial cellulose fibrils in Agrobacterium tumefaciens infection. J Bacteriol 154: 906-915.

MATTHYSSEAG (1987). Characterization of nonattaching mutants of Agrobacterium tumefaciens. J Bacteriol 169: 313-323.

MATTHYSSE A G, MARRY M, KRALL L, KAYE M, RAMEY B E, FUQUA C, WHITE A $R$ (2005). The effect of cellulose overproduction on binding and biofilm formation on roots by Agrobacterium tumefaciens. Mol Plant Microbe Interact 18: 1002-1010.

MATTHYSSE A G, MCMAHAN S (1998). Root colonization by Agrobacterium tumefaciens is reduced in cel, attB, attD, and attR mutants. Appl Environ Microbiol 64: 2341-2345.

MAURY S, DELAUNAY A, MESNARD F, CRONIER D, CHABBERT B, GEOFFROY P, LEGRAND M (2010). O-methyltransferase(s)-suppressed plants produce lower amounts of phenolic virinducers and are less susceptible to Agrobacterium tumefaciens infection. Planta 232: 975-986.

MAYERHOFER R, KONCZ-KALMAN Z, NAWRATH C, BAKKEREN G, CRAMERI A, ANGELIS K, REDEI G P, SCHELL J, HOHN B, KONCZ C (1991). T-DNA integration: a mode of illegitimate recombination in plants. EMBO J 10: 697-704.

MELANSON D, CHILTON M D, MASTERS-MOORE D. CHILTON W S (1997). A deletion in an indole synthase gene is responsible for the DIMBOA-deficient phenotype of bxbx maize. Proc Natl Acad Sci USA 94: 13345-13350.

MELCHERSLS, MARONEYMJ, DENDULK-RASA, THOMPSONDV, VAN VUUREN HA, SCHILPEROORT RA, HOOYKAASP J (1990). Octopine and nopaline strains of Agrobacterium tumefaciens differ in virulence; molecular characterization of the virF locus. Plant Mol Biol 14: 249-259.

MELCHERS L S, REGENSBURG-TUINK A J, SCHILPEROORT R A, HOOYKAAS $\mathrm{PJ}$ (1989a). Specificity of signal molecules in the activation of Agrobacterium virulence gene expression. Mol Microbiol 3: 969-977.

MELCHERS L S, REGENSBURG-TUINK T J, BOURRET R B, SEDEE N J, SCHILPEROORT R A, HOOYKAAS P J (1989b). Membrane topology and functional analysis of the sensory protein VirA of Agrobacterium tumefaciens. EMBO J 8: 1919-1925.

MICHIELSE C B, HOOYKAAS P J, VAN DEN HONDEL C A, RAM A F (2005). Agrobacterium-mediated transformation as a tool for functional genomics in fungi. Curr Genet 48: 1-17.

MIGUEL C, MARUM L (2011). An epigenetic view of plant cells cultured in vitro: somaclonal variation and beyond. J Exp Bot 62: 3713-3725.

MYSORE K S, NAM J, GELVIN S B (2000). An Arabidopsis histone H2A mutant is deficient in Agrobacterium T-DNAintegration. Proc Nat/Acad SciUSA 97: 948-953.

NAIR G R, LIU Z, BINNS AN (2003). Reexamining the role of the accessory plasmid pAtC58 in the virulence of Agrobacterium tumefaciens strain C58. Plant Physiol 133: 989-999

NAM J, MYSORE K S, ZHENG C, KNUE M K, MATTHYSSE A G, GELVIN S B (1999). Identification of T-DNA tagged Arabidopsis mutants that are resistant to transformation by Agrobacterium. Mol Gen Genet 261: 429-438.

NARASIMHULU S B, DENG X B, SARRIA R, GELVIN S B (1996). Early transcription of Agrobacterium T-DNA genes in tobacco and maize. Plant Cell 8: 873-886.

NEWELL C A (2000). Plant transformation technology. Developments and applications. Mol Biotechnol 16: 53-65.

NISHIZAWA-YOKOI A, NONAKA S, SAIKA H, KWON Y I, OSAKABE K, TOKI S
(2012). Suppression of Ku70/80 or Lig4 leads to decreased stable transformation and enhanced homologous recombination in rice. New Phytol 196: 1048-1059.

NONAKA S, SUGAWARA M, MINAMISAWA K, YUHASHI K I, EZURA H (2008a). 1-aminocyclopropane-1-carboxylate deaminase-producing Agrobacterium tumefaciens has higher ability for gene transfer into plant cells. Appl Environ Microbiol 74: 2526-2528.

NONAKA S, YUHASHI K I, TAKADA K, SUGAWARE M, MINAMISAWA K, EZURA H (2008b). Ethylene production in plants during transformation suppresses virgene expression in Agrobacterium tumefaciens. New Phytol 178: 647-656.

OTTEN L, DE GREVE H, LEEMANS J, HAIN R, HOOYKAAS P J, SCHELL F M (1984). Restoration of virulence of vir region mutants of $A$. tumefaciens strain B6S3 by coinfection with normal and mutant Agrobacterium strains. Mol Gen Genet 195: 159-163.

PANSEGRAU W, SCHOUMACHER F, HOHN B,LANKA E (1993). Site-specific cleavage and joining of single-stranded DNA by VirD2 protein of Agrobacterium tumefaciens Ti plasmids: analogy to bacterial conjugation. Proc Natl Acad Sci USA 90: 11538-11542.

PENG W T, LEE Y W, NESTER E W (1998). The phenolic recognition profiles of the Agrobacterium tumefaciens VirA protein are broadened by a high level of the sugar binding protein ChvE. J Bacteriol 180: 5632-5638.

PIERS K L, HEATH J D, LIANG X, STEPHENS K M, NESTER E W (1996). Agrobacterium tumefaciens-mediated transformation of yeast. Proc Natl Acad Sci USA 93: 1613-1618.

PRUSS G J, NESTER E W, VANCE V (2008). Infiltration with Agrobacterium tumefaciens induces host defense and development-dependent responses in the infiltrated zone. Mol Plant Microbe Interact 21: 1528-1538.

QU F, MORRIS T J (2005). Suppressors of RNA silencing encoded by plant viruses and their role in viral infections. FEBS Lett 579: 5958-5964.

REGENSBURG-TUINK A J,HOOYKAAS P J (1993). Transgenic N. glauca plants expressing bacterial virulence gene virf are converted into hosts for nopaline strains of $A$. tumefaciens. Nature 363: 69-71.

RODRIGUEZ-NAVARRO D N, DARDANELLI M S, RUIZ-SAINZ J E (2007). Attachment of bacteria to the roots of higher plants. FEMS Microbiol Lett 272: 127-136.

SAGULENKO V, SAGULENKO E, JAKUBOWSKI S, SPUDICH E, CHRISTIE P J (2001). VirB7 lipoprotein is exocellular and associates with the Agrobacterium tumefaciens T pilus. J Bacteriol 183: 3642-3651.

SAHI S V, CHILTON M D, CHILTON W S (1990). Corn metabolites affect growth and virulence of Agrobacterium tumefaciens. Proc Natl Acad Sci USA 87: 3879-3883.

SALMAN H, ABU-ARISHA, OLIELS, LOYTERA, KLAFTER J, GRANEK R, ELBAUM M (2005). Nuclear localization signal peptides induce molecular delivery along microtubules. Biophys J 89: 2134-2145.

SALOMON S, PUCHTA H (1998). Capture of genomic and T-DNA sequences during double-strand break repair in somatic plant cells. EMBO J 17: 6086-6095.

SCHRAMMEIJER B, RISSEEUW E, PANSEGRAU W, REGENSBURG-TUINK T J, CROSBY W L, HOOYKAAS P J (2001). Interaction of the virulence protein VirF of Agrobacterium tumefaciens with plant homologs of the yeast Skp1 protein. Curr Biol 11: 258-262.

SHAKED H, MELAMED-BESSUDO C, LEVY A A (2005). High-frequency gene targeting in Arabidopsis plants expressing the yeast RAD54 gene. Proc Natl Acad Sci USA 102: 12265-12269.

SHIMODAN, TOYODA-YAMAMOTOA, AOKIS, MACHIDAY (1993). Genetic evidence for an interaction between the VirA sensor protein and the ChvE sugar-binding protein of Agrobacterium. J Biol Chem 268: 26552-26558.

SHIMODA N, TOYODA-YAMAMOTO A, NAGAMINE J, USAMI S, KATAYAMA M, SAKAGAMI Y, MACHIDA Y (1990). Control of expression of Agrobacterium vir genes by synergistic actions of phenolic signal molecules and monosaccharides. Proc Natl Acad Sci USA 87: 6684-6688.

SINGER K, SHIBOLETH Y M, LI J, TZFIRA T (2012). Formation of complex extrachromosomal T-DNA structures in Agrobacterium tumefaciens-infected plants. Plant Physiol 160: 511-522.

SMIT G, LOGMAN T J, BOERRIGTER M E, KIJNE J W, LUGTENBERG B J (1989). Purification and partial characterization of the Rhizobium leguminosarum biovar viciae $\mathrm{Ca}_{2}{ }^{+}$-dependent adhesin, which mediates the first step in attachment of cells of the family Rhizobiaceae to plant root hair tips. J Bacteriol 171: 4054-4062.

SONTI R V, CHIURAZZI M, WONG D, DAVIES C S, HARLOW G R, MOUNT D W, SIGNER E R (1995). Arabidopsis mutants deficient in T-DNA integration. Proc 
Natl Acad Sci USA 92: 11786-11790.

STACHELSE, MESSENS E, VAN MONTAGU M, ZAMBRYSKI P (1985). Identification of the signal molecules produced by the wounded plant cells that activate T-DNA transfer in Agrobacterium tumefaciens. Nature 318: 624-629.

STACHEL S E, ZAMBRYSKI P C (1986). virA and virG control the plant-induced activation of the T-DNA transfer process of $A$. tumefaciens. Cell 46: 325-333.

SWART S, LOGMAN T J, SMIT G, LUGTENBERG B J, KIJNE J W (1994). Purification and partial characterization of a glycoprotein from pea (Pisum sativum) with receptor activity for rhicadhesin, an attachment protein of Rhizobiaceae. Plant Mol Biol 24: 171-183.

TAO Y, RAO P K, BHATTACHARJEE S, GELVIN S B (2004). Expression of plant protein phosphatase $2 \mathrm{C}$ interferes with nuclear import of the Agrobacterium Tcomplex protein VirD2. Proc Natl Acad Sci USA 101: 5164-5169.

TEGTMEYER N, WESSLER S, BACKERT S (2011). Role of the cag-pathogenicity island encoded type IV secretion system in Helicobacter pylori pathogenesis. FEBS J 278: 1190-1202.

THANASSI D G, BLISKA J B, CHRISTIE P J (2012). Surface organelles assembled by secretion systems of Gram-negative bacteria: diversity in structure and function. FEMS Microbiol Rev 36: 1046-1082.

TINLAND B (1996). The integration of T-DNA into plant genomes. Trends Plant Sci 1: $178-184$

TINLAND B, KOUKOLIKOVA-NICOLA Z, HALL M N, HOHN B (1992). The T-DNAlinked VirD2 protein contains two distinct functional nuclear localization signals. Proc Natl Acad Sci USA 89: 7442-7446.

TINLAND B, SCHOUMACHER F, GLOECKLER V, BRAVO-ANGEL A M, HOHN B (1995). The Agrobacterium tumefaciens virulence D2 protein is responsible for precise integration of T-DNA into the plant genome. EMBO J 14: 3585-3595.

TOMLINSON A D, FUQUA C (2009). Mechanisms and regulation of polar surface attachment in Agrobacterium tumefaciens. Curr Opin Microbiol 12: 708-714.

TOMLINSONAD, RAMEY-HARTUNG B, DAY TW, MERRITT P M, FUQUAC (2010). Agrobacterium tumefaciens ExoR represses succinoglycan biosynthesis and is required for biofilm formation and motility. Microbiology 156: 2670-2681.

TZFIRA T (2006). On tracks and locomotives: the long route of DNA to the nucleus. Trends Microbiol 14: 61-63.

TZFIRA T, CITOVSKY V (2006). Agrobacterium-mediated genetic transformation of plants: biology and biotechnology. Curr Opin Biotechnol 17: 147-154.

TZFIRAT, FRANKMAN LR, VAIDYAM, CITOVSKY V (2003). Site-specific integration of Agrobacterium tumefaciens T-DNA via double-stranded intermediates. Plant Physiol 133: 1011-1023.

TZFIRAT, LI J, LACROIXB, CITOVSKY V (2004a). Agrobacterium T-DNAintegration: molecules and models. Trends Genet 20: 375-383.

TZFIRA T, RHEE Y, CHEN M H, KUNIK T, CITOVSKY V (2000). Nucleic acid transport in plant-microbe interactions: the molecules that walk through the walls. Annu Rev Microbiol 54: 187-219.

TZFIRAT, VAIDYAM, CITOVSKY V (2001). VIP1, an Arabidopsis protein that interacts with Agrobacterium VirE2, is involved in VirE2 nuclear import and Agrobacterium infectivity. EMBO J 20: 3596-3607.

TZFIRA T, VAIDYA M, CITOVSKY V (2002). Increasing plant susceptibility to Agrobacterium infection by overexpression of the Arabidopsis nuclear protein VIP1. Proc Natl Acad Sci USA 99: 10435-10440.

TZFIRA T, VAIDYA M, CITOVSKY V (2004b). Involvement of targeted proteolysis in plant genetic transformation by Agrobacterium. Nature 431: 87-92.

TZFIRAT, LACROIXB, CITOVSKY V. (2005). Nuclear import of Agrobacterium T-DNA. In: Nuclear import and export in plants and animals (Ed. T. Tzfira and V. Citovsky). Kluwer academic / Plenum publisher, New York, USA, pp 83-99.

VAGHCHHIPAWALA Z E, VASUDEVAN B, LEE S, MORSY M R, MYSORE K S (2012). Agrobacterium may delay plant nonhomologous end-joining DNA repair via XRCC4 to favor T-DNA integration. Plant Cell 24: 4110-4123.

VANATTIKUM H, BUNDOCK P, HOOYKAASP J (2001). Non-homologous end-joining proteins are required for Agrobacterium T-DNAintegration. EMBOJ20:6550-6558.

VAN ATTIKUM H, HOOYKAAS P J (2003). Genetic requirements for the targeted integration of Agrobacterium T-DNA in Saccharomyces cerevisiae. Nucleic Acids Res 31: 826-832.

VEENA, JIANG H, DOERGE R W, GELVIN S B (2003). Transfer of T-DNA and Vir proteins to plant cells by Agrobacterium tumefaciens induces expression of host genes involved in mediating transformation and suppresses host defense gene expression. Plant J 35: 219-236.

VERGUNST A C, SCHRAMMEIJER B, DEN DULK-RAS A, DE VLAAM C M, REGENSBURG-TUINK T J, HOOYKAAS P J (2000). VirB/D4-dependent protein translocation from Agrobacterium into plant cells. Science 290: 979-982.

VILLEMONTE, DUBOISF, SANGWANRS, VASSEURG, BOURGEOISY, SANGWANNORREEL B S (1997). Role of the host cell cycle in the Agrobacterium-mediated genetic transformation of Petunia: evidence of an S-phase control mechanism for T-DNA transfer. Planta 201: 160-172.

VLOT A C, DEMPSEY D A, KLESSIG D F (2009). Salicylic acid, a multifaceted hormone to combat disease. Annu Rev Phytopathol 47: 177-206.

VOINNET O, RIVAS S, MESTRE P, BAULCOMBE D (2003). An enhanced transient expression system in plants based on suppression of gene silencing by the p19 protein of tomato bushy stunt virus. Plant J 33: 949-956.

WAGNER V T, MATTHYSSE A G (1992). Involvement of a vitronectin-like protein in attachment of Agrobacterium tumefaciens to carrot suspension culture cells. $J$ Bacteriol 174: 5999-6003.

WARD D, BARNES W M (1988). VirD2 protein of Agrobacterium tumefaciens very tightly linked to the 5' end of T-strand. Science 242: 927-930

WINANS S C, KERSTETTER RA, NESTER E W (1988). Transcriptional regulation of the virA and virGgenes of Agrobacterium tumefaciens. J Bacteriol 170: 4047-4054.

YI H, MYSORE K S, GELVIN S B (2002). Expression of the Arabidopsis histone H2A-1 gene correlates with susceptibility to Agrobacterium transformation. Plant J 32: 285-298.

YOUNG C, NESTER E W (1988). Association of the VirD2 protein with the 5' end of T strands in Agrobacterium tumefaciens. J Bacteriol 170: 3367-3374.

YUAN Z C, EDLIND M P, LIU P, SAENKHAM P, BANTA L M, WISEAA, RONZONE E, BINNS A N, KERR K, NESTER E W (2007). The plant signal salicylic acid shuts down expression of the vir regulon and activates quormone-quenching genes in Agrobacterium. Proc Natl Acad Sci USA 104: 11790-11795.

YUAN Z C, LIU P, SAENKHAM P, KERR K, NESTER E W (2008). Transcriptome profiling and functional analysis of Agrobacterium tumefaciens reveals a general conserved response to acidic conditions ( $\mathrm{pH}$ 5.5) and a complex acid-mediated signaling involved in Agrobacterium-plant interactions. J Bacteriol 190: 494-507.

ZALTSMANA, KRICHEVSKYA, KOZLOVSKY S V, YASMIN F, CITOVSKY V (2010a). Plant defense pathways subverted by Agrobacterium for genetic transformation. Plant Signal Behav 5.

ZALTSMAN A, KRICHEVSKY A, LOYTER A, CITOVSKY V (2010b). Agrobacterium induces expression of a host F-box protein required for tumorigenicity. Cell Host Microbe 7: 197-209.

ZALTSMAN A, LACROIX B, GAFNI Y, CITOVSKY V (2013). Disassembly of synthetic Agrobacterium T-DNA-protein complexes via the host SCF ${ }^{\mathrm{BF}}$ ubiquitin-ligase complex pathway. Proc Natl Acad Sci USA 110: 169-174.

ZAMBRYSKI P (1992). Chronicles from the Agrobacterium-plant cell DNA transfer story. Annu Rev Plant Physiol Plant Mol Biol 43: 465-490.

ZHANG J, BOONE L, KOCZ R, ZHANG C, BINNS A N, LYNN D G (2000). At the maize/Agrobacterium interface: natural factors limiting host transformation. Chem Biol 7: 611-621.

ZHUY, NAM J, CARPITANC, MATTHYSSEAG, GELVIN SB (2003a). Agrobacteriummediated root transformation is inhibited by mutation of an Arabidopsis cellulose synthase-like gene. Plant Physiol 133: 1000-1010.

ZHU Y, NAM J, HUMARA J M, MYSORE K S, LEE L Y, CAO H, VALENTINE L, LI J, KAISER A D, KOPECKY A L, et al. (2003b). Identification of Arabidopsis rat mutants. Plant Physiol 132: 494-505.

ZIEMIENOWICZA, GORLICHD, LANKAE, HOHNB, ROSSI L (1999). Import of DNA into mammalian nuclei by proteins originating from a plant pathogenic bacterium. Proc Natl Acad Sci USA 96: 3729-3733.

ZIEMIENOWICZ A, MERKLE T, SCHOUMACHER F, HOHN B, ROSSI L (2001). Import of Agrobacterium T-DNA into plant nuclei: two distinct functions of VirD2 and VirE2 proteins. Plant Cell 13: 369-383.

ZIEMIENOWICZ A, TINLAND B, BRYANT J, GLOECKLER V, HOHN B (2000). Plant enzymes but not Agrobacterium VirD2 mediate T-DNA ligation in vitro. Mol Cell Biol 20: 6317-6322.

ZIPFEL C, KUNZE G, CHINCHILLA D, CANIARD A, JONES J D, BOLLER T, FELIX $G$ (2006). Perception of the bacterial PAMP EF-Tu by the receptor EFR restricts 
Agrobacterium-mediated transformation. Cell 125: 749-760.

ZRACHYA A, GLICK E, LEVY Y, ARAZI T, CITOVSKY V, GAFNI Y (2007). Suppressor of RNA silencing encoded by Tomato yellow leaf curl virus-Israel. Virology 358: 159-165.
ZUPAN J R, CITOVSKY V, ZAMBRYSKI P (1996). Agrobacterium VirE2 protein mediates nuclear uptake of single-stranded DNA in plant cells. Proc Natl Acad Sci USA 93: 2392-2397.

ZUPAN J R, ZAMBRYSKI P (1995). Transfer of T-DNA from Agrobacterium to the plant cell. Plant Physiol 107: 1041-1047.

\section{Further Related Reading, published previously in the Int. J. Dev. Biol.}

Common themes in siRNA-mediated epigenetic silencing pathways André Verdel, Aurélia Vavasseur, Madalen Le Gorrec and Leila Touat-Todeschini Int. J. Dev. Biol. (2009) 53: 245-257

http://www.intjdevbiol.com/web/paper/082691av

\section{Plant microRNAs and development}

Sara Jover-Gil, Héctor Candela and María-Rosa Ponce

Int. J. Dev. Biol. (2005) 49: 733-744

Historical perspectives on plant developmental biology

Mieke Van Lijsebettens and Marc Van Montagu

Int. J. Dev. Biol. (2005) 49: 453-465

Molecular-genetic approach to study plant growth and development M Van Montagu, M Van Lijsebettens and D Inzé

Int. J. Dev. Biol. (1996) 40: S49-S50

Mechanisms of the proliferation and differentiation of plant cells in cell culture systems H Fukuda, M Ito, M Sugiyama and A Komamine Int. J. Dev. Biol. (1994) 38: 287-299

5 yr ISI Impact Factor $(2011)=2.959$
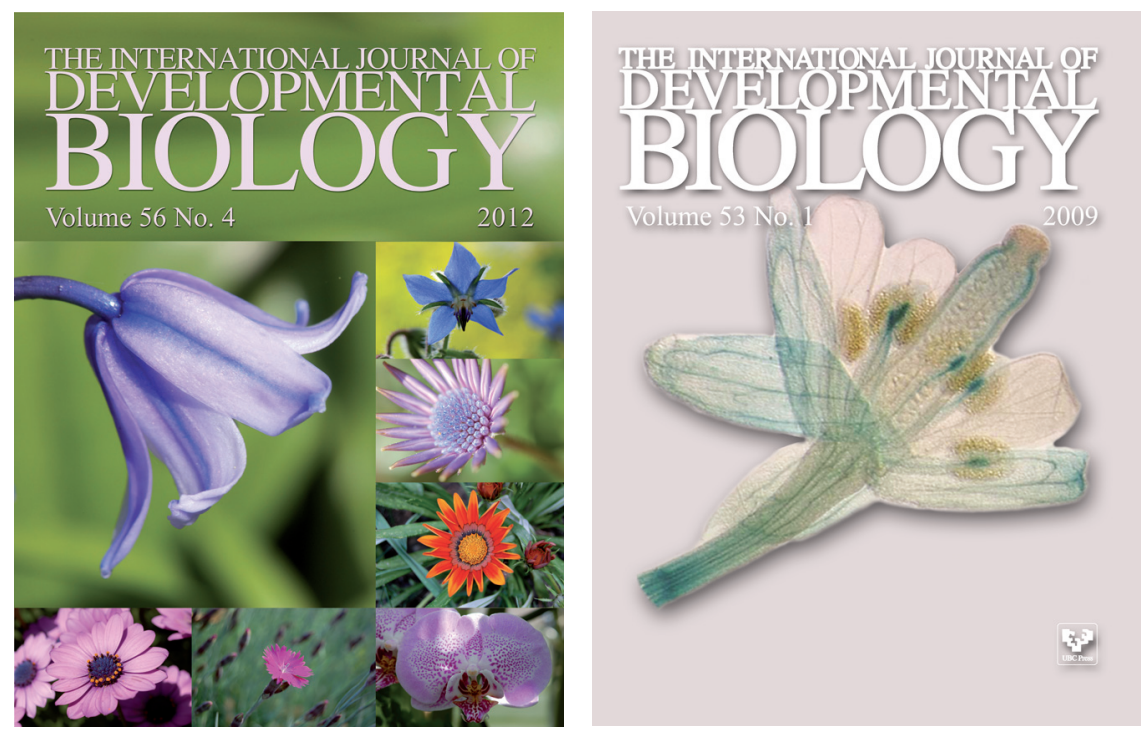
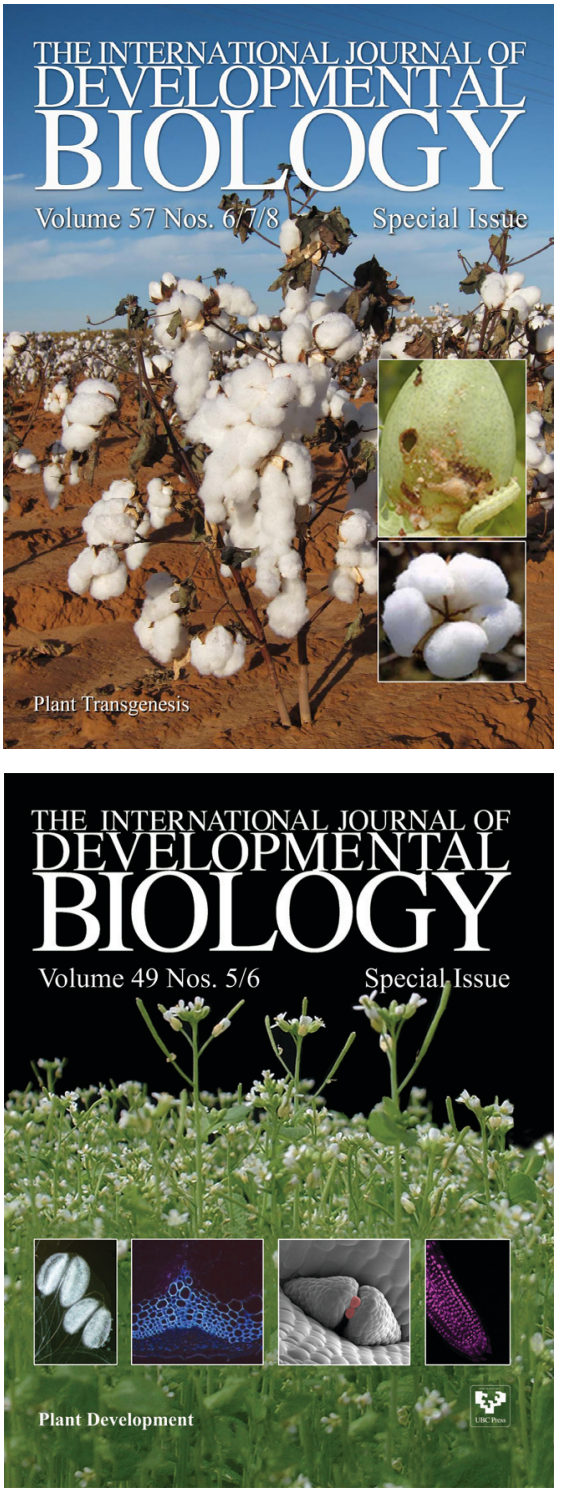